\title{
Middle Palaeogene dinoflagellate cysts from Tierra del Fuego, Argentina: biostratigraphy and palaeoenvironments
}

\author{
G. R. GUERSTEIN ${ }^{1}$, M. V. GULER ${ }^{1}$, G. L. WILLIAMS ${ }^{2}$, R. A. FENSOME ${ }^{2} \&$ J. O. CHIESA ${ }^{3}$ \\ ${ }^{1}$ INGEOSUR - Consejo Nacional de Investigaciones Científicas y Técnicas - Departamento de Geología, Universidad Nacional del Sur, \\ San Juan 670 (8000) Bahía Blanca, Argentina (e-mail: gmguerst@criba.edu.ar) \\ ${ }^{2}$ Natural Resources Canada, Geological Survey of Canada (Atlantic), PO Box 1006, Dartmouth, Nova Scotia, B2Y 4A2 Canada \\ ${ }^{3}$ Departamento de Geología, Universidad Nacional de San Luis, Ejército de los Andes 950 (5700) San Luis, Argentina
}

\begin{abstract}
Palynological data from four surface sections in northern Tierra del Fuego, southern Argentina, provide a biostratigraphical and palaeoenvironmental framework for the lower member of the La Despedida Formation and the Cabo Peña Formation in their type areas. Selected dinoflagellate cyst (dinocyst) events indicate that the age of the lower member of the La Despedida Formation is Middle Eocene and that of the Cabo Peña Formation is Late Eocene-earliest Oligocene. The age assigned to the La Despedida Formation agrees with determinations based on calcareous microfossils, but there is a potential discrepancy regarding the Cabo Peña Formation. According to recent stratigraphic studies, the Cabo Domingo Group, which includes the Cabo Peña Formation, is Late Eocene-Miocene in age. The palynomorph assemblages from the lower member of the La Despedida Formation contain the endemic 'Transantarctic Flora', which reflects marginal marine conditions. The maximum abundance of Enneadocysta spp. reflects more open-sea conditions and a warming event during the late Middle Eocene. The lower part of the Cabo Peña Formation has a high ratio of dinocysts to sporomorphs and an abundance of Nematosphaeropsis lemniscata, Reticulatosphaera actinocoronata and Impagidinium spp., suggesting an oceanic to outer neritic environment. Abundant Gelatia inflata and protoperidiniacean cysts indicate cool surface waters rich in dissolved nutrients. These cold-water markers may reflect the development of the Antarctic Circumpolar Current, an important event in the transition from a greenhouse to an icehouse climate mode. Toward the top of the sections, the lower ratios of dinocysts to sporomorphs, as well as the composition of the dinocyst assemblages, reflect a neritic rather than an oceanic setting. This palynological change may be due to eustatic sea-level lowering caused by cooling during the latest Eocene-earliest Oligocene. A new species, Spiniferites scalenus, is described and the new combination Lingulodinium echinatum proposed; an emendation for the latter species is also proposed. J. Micropalaeontol., 27(1): 75-94, May 2008.
\end{abstract}

KEYWORDS: Dinoflagellates, Palaeogene, biostratigraphy, palaeoenvironments, Argentina

\section{INTRODUCTION}

Global cooling during the Palaeogene is demonstrated by the ${ }^{18} \mathrm{O}$ record from benthic foraminifera (Zachos et al., 2001). The record shows a gradual decline in global temperature from about $50 \mathrm{Ma}$ (Early Eocene), with a significant coolingglaciation event (Oi-1) at the Eocene-Oligocene boundary (33$34 \mathrm{Ma}$ ). This event was followed by a cold interval of about 12 million years, with the East Antarctica ice sheet growing during this time.

The mechanisms that led to the abrupt Eocene-Oligocene climate deterioration and the growth of extensive ice sheets in Antarctica is the subject of debate. Several authors (e.g. Kennett, 1977; Barker, 2001) considered that Palaeogene cooling was caused by thermal isolation of Antarctica, resulting from the opening of deep-water gateways (Tasman Gateway and Drake Passage) and subsequent development of the Antarctic Circumpolar Current (ACC). Other models are based on a decline in $\mathrm{CO}_{2}$ (for example, DeConto \& Pollard, 2003; Huber et al., 2004; Pagani et al., 2005), the closure of a circumequatorial seaway (Lawver \& Gahagan, 2003) and tectonic uplift (Raymo \& Ruddiman, 1992). On the basis of marine geophysical data, Livermore et al. (2005) identified a major change in the relative motion of the South American and Antarctic plates at about $50 \mathrm{Ma}$. These authors considered that a connection between the Pacific and Atlantic oceans at Drake
Passage probably had a profound effect on global circulation and climate. Furthermore, they found a close correlation between crustal evolution and climatic events, reflected by the oxygen isotope record from benthic foraminifera.

The analysis of Palaeogene organic-walled, dinoflagellate cyst (dinocyst) assemblages provides a powerful biostratigraphic and palaeoclimatic tool (Sluijs et al., 2005 and references therein). Data from dinocysts play an important role in evaluating different general circulation models when reconstructing Southern Ocean circulation (Huber et al., 2004). Middle Palaeogene dinocyst information from Tierra del Fuego and Patagonia is potentially of great value but presently is scarce; moreover, most of the published papers are in Spanish (Menendez, 1965; Pöthe de Baldis, 1966; Archangelsky, 1969; Guerstein et al., 2002).

Marine Palaeogene rocks, which crop out in northern Tierra del Fuego, southern Argentina, contain diverse dinocyst assemblages. Guerstein et al. (2002) published the results of a preliminary study of dinocysts from the Cabo Peñas and Cerro Águila sections (Fig. 1) of the Cabo Peña Formation (De Ferrariis, 1938). According to these authors the sediments are Late Eocene-Early Oligocene.

In this paper, a detailed biostratigraphical analysis of the dinocyst assemblages from the Cabo Peña Formation in the Cabo Peñas and Cerro Águila sections is presented, plus new 


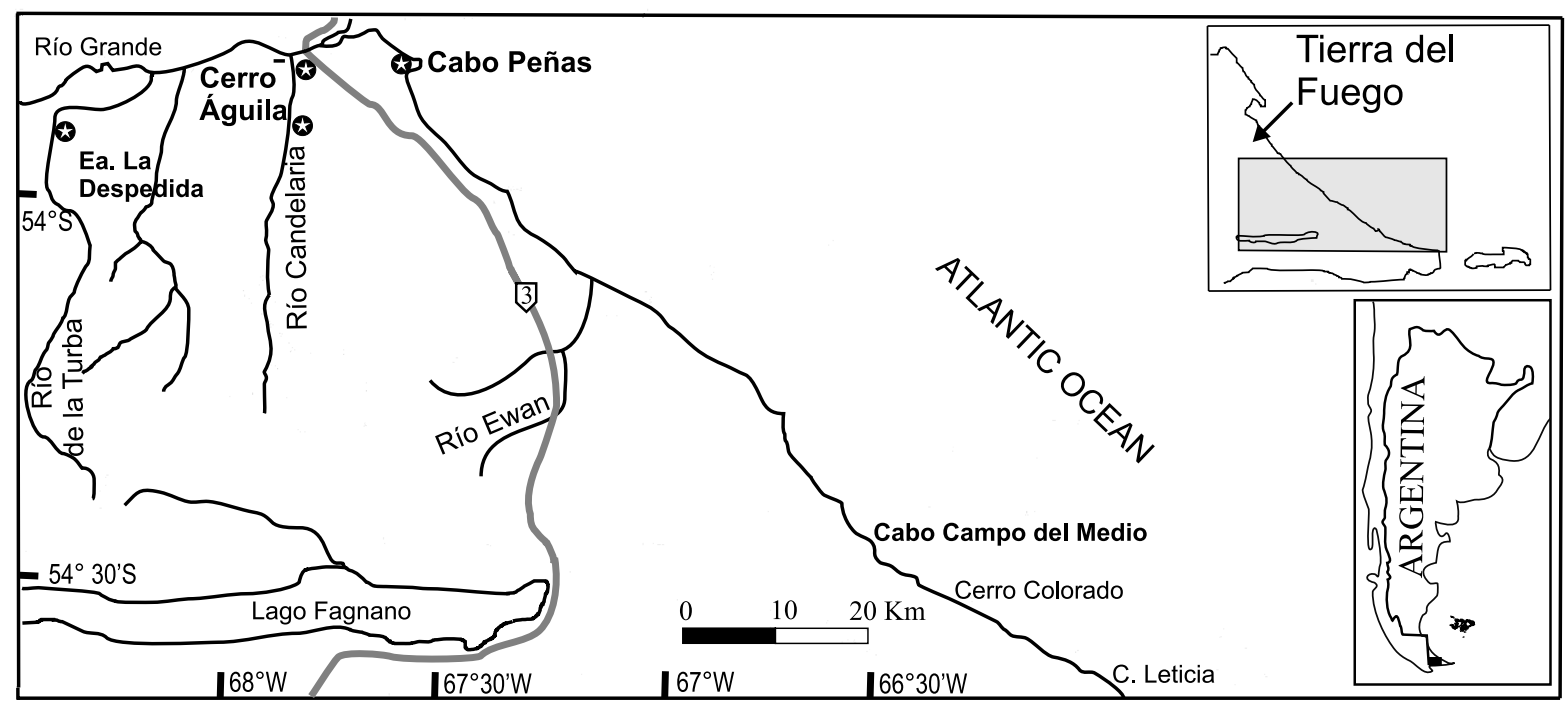

Fig. 1. Map of Tierra del Fuego showing studied localities.

data from the Río Candelaria section. Also included are results of analysis of the middle Eocene La Despedida Formation, which is exposed along the Río de la Turba (Fig. 1). Using this information, a reconstruction of palaeoclimatic trends for the middle Palaeogene of Tierra del Fuego is attempted. Observations from Tierra del Fuego are compared with coeval dinocyst datasets from other circum-Antarctic areas. The middle Palaeogene was a critical time in the evolution of Southern Ocean circulation and the transition from a greenhouse to an icehouse Earth.

\section{GEOLOGICAL SETTING}

The study area (Fig. 1) corresponds to the southernmost extraandean Austral (or Magallanes) Basin, which evolved during the Late Cretaceous-Cenozoic as a foreland basin to the north of the Andes Fueguinos (Biddle et al., 1986; Olivero \& Malumián, 1999). The tectonic history of the area during the Palaeogene is linked to the separation of South America from Antarctica and the opening of Drake Passage. According to Livermore et al. (2005), marine geophysical data reveal movement between the South American and Antarctic plates about 50 million years ago. These authors postulated that plate movements led to the formation of a gateway, about $1000 \mathrm{~m}$ deep, during the Middle Eocene. Although there were no significant changes near the Eocene-Oligocene boundary, continued extension developed a deep-water connection between 34 and $30 \mathrm{Ma}$.

Malumián (1999) proposed five transgressive-regressive events for extra-andean Patagonia in the Cenozoic. In northern Tierra del Fuego, two marine Palaeogene units crop out in small sections: the La Despedida Formation (Doello-Jurado, 1922); and the Cabo Peña Formation. These units correspond to the second and third cycles of Malumián (1999) and are of Middle Eocene and Late Eocene-Early Oligocene age respectively.

In a detailed stratigraphical and micropalaeontological study of northern Tierra del Fuego, Codignotto \& Malumián (1981) proposed that the Middle Eocene La Despedida Formation is overlain by the Cabo Peña Formation, although the contact is not exposed. Based on the presence of the foraminiferid
Elphidium saginatum, Codignotto \& Malumián (1981) and Malumián (1988) determined that the lower of their two informal members of the La Despedida Formation is Middle Eocene. The upper member contains the Cribrorotalia cf. C. tainuia assemblage and was considered late Middle to Late Eocene.

In a study of the 'Estratos de Leticia' (Furque \& Camacho, 1949), Olivero \& Malumián (1999) defined the La Despedida Group with three lithological units, from which the middle Leticia Formation middle unit, late Mid-Eocene in age, corresponds to the lower member of the La Despedida Formation outcropping along the Río de la Turba.

Codignotto \& Malumián (1981) and Malumián \& Caramés (1989) indicated a Late Eocene-Early Oligocene age for the Cabo Peña Formation at its type section. There the formation is overlain by the Cullen Formation (Petersen in Petersen \& Methol, 1948). Because of the presence of the MartinottiellaSpirosigmoilinella foraminiferid assemblage, the Cabo Peña was interpreted to be the same age in the Cerro Águila section, where it is overlain by the Cerro Águila Conglomerate (De Ferrariis, 1938).

Such was the state of knowledge until Malumián \& Olivero (2006) included the Cabo Peña Formation in the Cabo Domingo Group. They considered the age of the group to be Late Eocene-Middle Miocene. In a later paper, Olivero \& Malumián (2008, fig. 1) show an accompanying illustration, which implies that the age of the Cabo Peña is Late Chattian to Early Miocene. Unfortunately, the data substantiating this change are not given and the findings seem to be at odds with our age, based on the palynomorphs. Further studies are needed to resolve this issue.

\section{MATERIALS AND METHODS}

Processing of the samples for palynomorphs involved hydrochloric and hydrofluoric acids, followed by mild oxidation with nitric acid. The organic fraction was concentrated by separation in heavy liquids. The residues were sieved through screens of 10 , 25 and $180 \mu \mathrm{m}$ and stained with Bismarck C. Cabo Peña and Cerro Águila samples were processed at the Geological Survey 


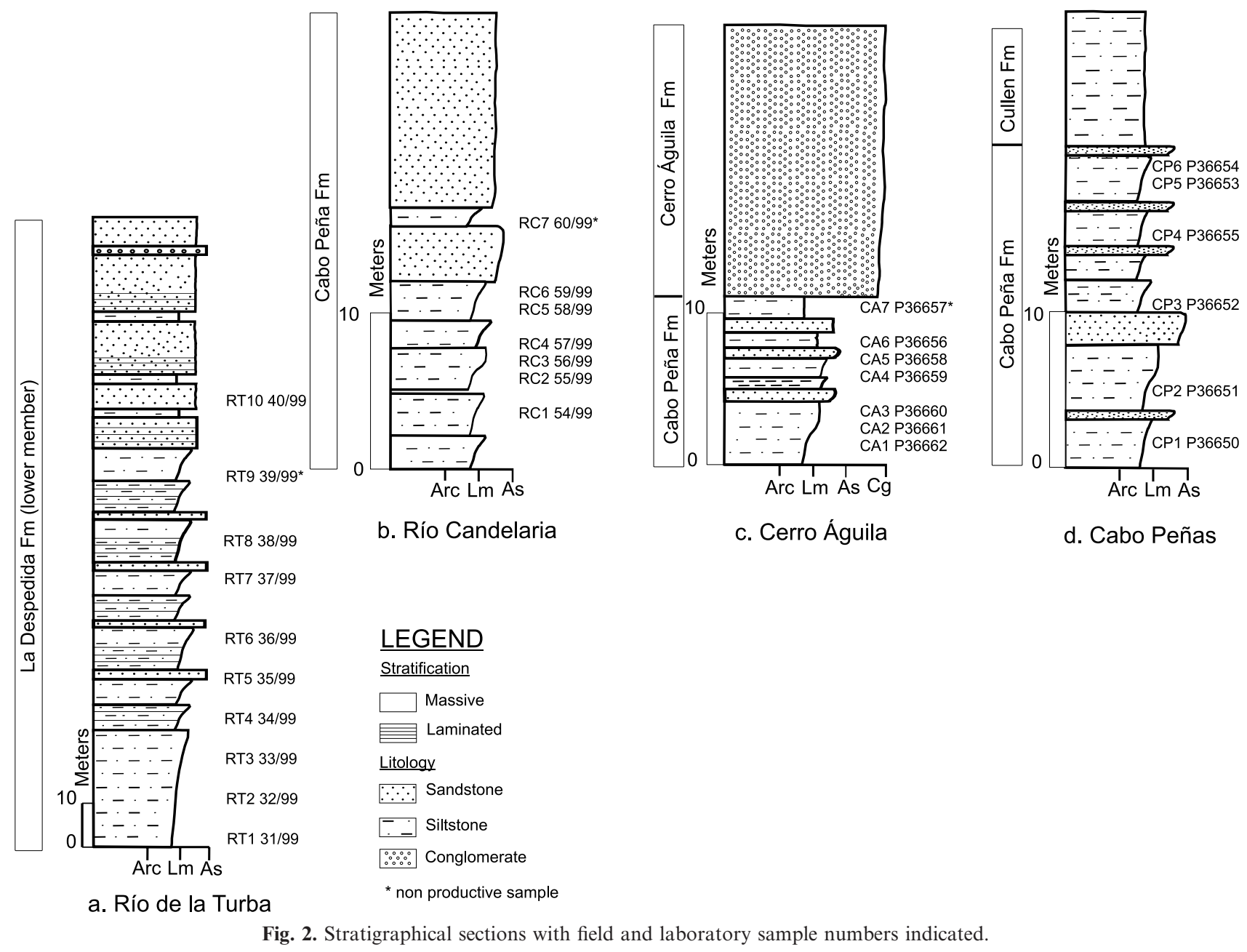

of Canada (Atlantic) and the residues mounted in elvacite and cellosize substitute. The Río Candelaria and La Despedida samples were processed at the Museo de Ciencias Naturales, Bernardino Rivadavia, Buenos Aires and the material was mounted in glycerine jelly.

Light microscopy was undertaken using a Nikon Eclipse 600 microscope and an attached Nikon Coolpix 1950 digital camera. Coordinates quoted are from the Vernier scale of microscope serial $n^{\circ} 772751$, and follow the sample and slide number for each illustrated specimen. England Finder (EF) references are provided in the explanations of plates. The type and figured specimens are housed in the collection of the Laboratorio de Palinología, Universidad Nacional del Sur, Bahía Blanca, Argentina. The ElectroScan E3 environmental scanning electron microscope (SEM) at the Geological Survey of Canada (Atlantic) was used under a partial pressure of water vapour. All the specimens were coated with gold prior to scanning. The geological time-scale of Gradstein et al. (2004) and - except where indicated - the dinoflagellate cyst nomenclature of Fensome \& Williams (2004) is followed.

The type section of La Despedida Formation is $550 \mathrm{~m}$ thick, with a mainly grey, pelitic lower member and a sandy upper member (Malumián, 1988). Ten samples were processed from the lower member for palynological analysis (Fig. 2a).
The Cabo Peña Formation consists mainly of siltstones grading upwards into silty sandstones. These are overlain by siltstones (Cullen Formation) at Cabo Peñas, by coarse-grained sandstones at Río Candelaria and by conglomeratic sandstones at Cerro Águila. The eighteen palynological samples that were productive were from the lower silty levels (Figs 2b-d).

\section{SYSTEMATIC PALYNOLOGY}

Division Dinoflagellata (Bütschli, 1885) Fensome et al., 1993 Subdivision Dinokaryota Fensome et al., 1993

Class Dinophyceae Pascher, 1914

Subclass Peridiniphycidae Fensome et al., 1993

Genus Brigantedinium Reid, 1977 ex Lentin \& Williams, 1993

$$
\text { Brigantedinium ? spp. }
$$$$
\text { (P1. 1, fig. 2) }
$$

Occurrence. Río Candelaria section, RC1-RC5.

Remarks. This group includes round-brown forms, which are generally poorly preserved and have a single, usually wrinkled wall. All the specimens have a thinner wall than modern representatives of Brigantedinium. This could be due to preservation, since a thin wall has also been observed in some species 

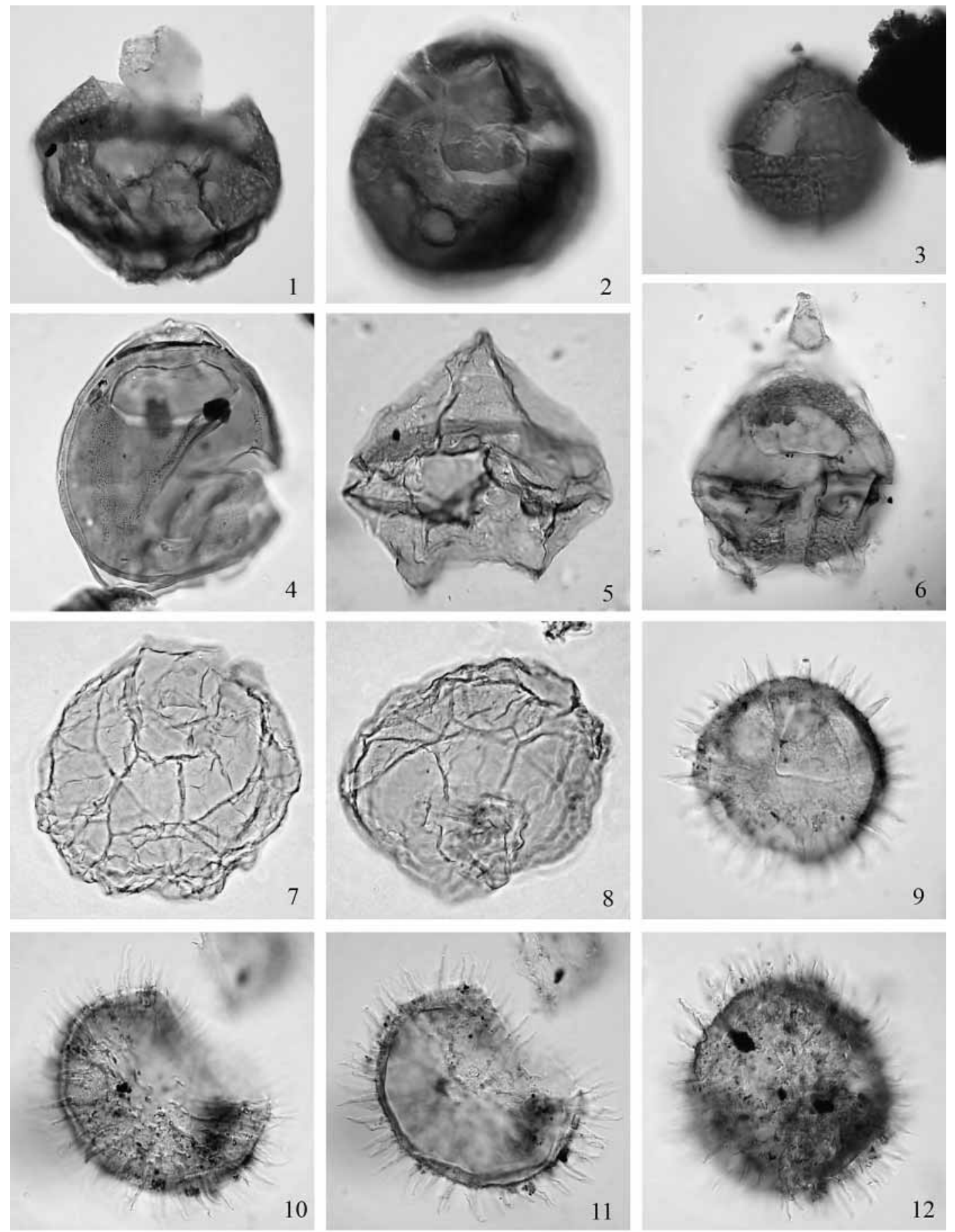

Explanation of Plate 1.

In Plates 1, 2, 4 and 5, the Laboratorio de Palinología, Universidad Nacional del Sur collection number is followed by slide numbers and England Finder references. A Nikon Eclipse 600 microscope fitted with Nomarski differential interference contrast (DIC) was used except where indicated. fig. 1. Batiacasphaera compta: LPUNS-RC4; $57 / 99$ (1); 31/102.5; N31/3; width $60 \mu \mathrm{m}$; ventral view, intermediate focus. fig. 2. Brigantedinium sp.: LPUNS-RC4; $57 / 99$ (1); 27/103.8; N28/1; width 56 um; dorsal view, high focus. fig. 3. Corrudinium incompositum: LPUNS-RC4; 57/99 (1); $36.3 / 107.3$; J37/3; length $47 \mu \mathrm{m}$, width $43 \mu \mathrm{m}$; right lateral dorsal view, high focus. fig. 4. Deflandrea convexa: LPUNS-CP3; P36652 (1); 43.2/100.7; Q44/3; central body width $75 \mu \mathrm{m}$; dorsal view, intermediate focus. fig. 5 Lejeunecysta sp.: LPUNS-RC5; 58/99 (1); 39.5/103.4; N40/3; width 65 $\mu$ m; ventral view, intermediate focus. fig. 6. Deflandrea scabrata: LPUNS-RC3; 56/99 (2); 52.2/103.2; O53/4; central body width $67 \mu \mathrm{m}$; ventral view, low focus. fig. 7. Gelatia inflata: LPUNS-CP3; P36652 (1); 42.6/95.8; V43/1; diameter 82 um; apical view, intermediate focus; phase contrast. fig. 8. Gelatia inflata: LPUNS-CP3; P36652 (1); 38/105; L38/4; diameter $86 \mu \mathrm{m}$; antapical view, intermediate focus; phase contrast. fig. 9. Lingulodinium machaerophorum: LPUNS-RC5; 58/99 (1); 37.3/111; E37/2; central body width $52 \mu \mathrm{m}$; ventral view, low focus showing the archaeopyle. figs 10-11. Lingulodinium echinatum: LPUNS-RC6; 59/99 (1); 48/97; T49/3; central body width $95 \mu \mathrm{m}$; left lateral view - 10, high focus, 11, intermediate focus. fig. 12. Lingulodinium echinatum: LPUNS-RC6; $59 / 99$ (1); 29.2/100; Q29/4; central body width $64 \mu$ m; ventral view, high focus. 
of Brigantedinium from Middle to Upper Miocene deposits in the Colorado Basin, eastern Argentina (Guler, 2003). The shape of the archaeopyle cannot be determined in most of the specimens.

Genus Lingulodinium Wall, 1967 emend. Dodge, 1989

Lingulodinium echinatum Menéndez, 1965 n. comb., emend. (P1. 1, figs 10-12)

Basionym. Hystrichosphaeridium? echinatum Menéndez, 1965: 12-13; pl. 2, fig. 9.

Neotype. Plate 1, figs 10-11. Río Candelaria section, $11 \mathrm{~m}$ above the base. UNS RC 59/99- 48/97 EF: T 49/3. Designated here.

Emended description. Chorate cysts with a subspherical central body, covered with numerous nontabular processes. Processes relatively thin, flexuous, flattened, with acuminate tips and with a length about one quarter of the cyst diameter. The wall is two-layered, with a thick endophragm and a thin, densely granular periphragm. Granules are distributed evenly along the processes. Archaeopyle precingular, type $\mathrm{P}$ or $2 \mathrm{P}$.

Dimensions. Range of five specimens-central body 54-68 $\mu \mathrm{m}$; length of processes $14-17 \mu \mathrm{m}$.

Occurrence. Río de la Turba section, RT7, RT9; Río Candelaria section, RC1-RC3, RC5-RC6.

Remarks. In the protologue, Menéndez (1965) described this species as having processes that are acuminate or truncate, or that have tips with a small expansion that appears bifurcate. However, the specimens here have processes with thin, flexuous and strongly acuminate tips; bifurcate or capitate tips were not observed. The apparently truncate ends and small bifurcations described by Menéndez (1965) possibly reflect the flexuous structure of the processes. His specimens are smaller than those described from the Cabo Peña Formation. Because of poor preservation of the slides, the holotype or any topotype material could not be located. Thus, a neotype is designated. Lingulodinium echinatum closely resembles Lingulodinium pycnospinosum but is considerably larger and has granulate processes that are not perforated by pores.

Genus Spiniferites Mantell, 1850 emend. Sarjeant, 1970

Spiniferites scalenus sp. nov.

(Pl. 2, figs 3-8; Pl. 3, figs 6-12)

Derivation of name. From the Latin 'scalenus', meaning 'unequal', in reference to the uneven height of the sutural crests.

Diagnosis. A species of Spiniferites with an elongate central body, bearing relatively short, trifurcate gonal processes, joined at their base by sutural crests of variable height. The crests vary even within a single specimen, from simple, sutural low ridges to high, membranous septa, almost reaching the distal expansion of the processes.

Holotype. Plate 2, figs 3-4. Cerro Águila section, $0.5 \mathrm{~m}$ above the base. UNS CA1-P34662-1: 48/108 EF: H 49/3.

Locality and horizon. Cerro Águila Section, northeast Tierra del Fuego, Argentina. Lower part of the Cabo Peña Formation; Upper Eocene.

Description. Chorate cysts with an elongate central body bearing trifurcate gonal processes. Most of the processes are short, membranous, subtriangular in cross-section, with a central solid stem. Terminations are usually trifurcate with bifurcate ends. Generally, the processes are connected at their bases by high membranous septa of variable height. Specimens with the highest crests do not have stems but simply a trifurcate expansion at the gonal junctions of septa (Pl. 3, figs 6, 8). Septa margins are irregularly undulate to denticulate (Pl. 3, figs 5-12). The endophragm is smooth and the periphragm is microgranular to granular. The archaeopyle is precingular, type $\mathrm{P}$, resulting from the loss of the $3^{\prime \prime}$ plate, and with a free operculum. Paratabulation gonyaulacoidean, defined by membranous septa and/or low sutural ridges and by the gonal processes. Plates $1^{\prime}$ and $4^{\prime}$ are generally fused (Pl. 3, figs 6, 8).

Dimensions. Holotype - central body width $38 \mu \mathrm{m}$; central body length $47 \mu \mathrm{m}$; height of sutural septa $5 \mu \mathrm{m}$. Range of ten specimens - central body width $28-45 \mu \mathrm{m}$; central body length 35-47 $\mu \mathrm{m}$; height of sutural septa $1-7 \mu \mathrm{m}$.

Occurrence. Río de la Turba section, RT6, RT10; Cabo Peñas section, CP1-CP2; Cerro Águila section, CA1-CA6; Río Candelaria section, R1-R2, R4-R5.

Remarks. The new species differs from other species of Spiniferites by having crests of variable height. Several of the observed specimens have septa rising up to the base of the furcate process terminations. In such cases they resemble species of the genus Impagidinium (P1. 2, figs 3-4; Pl. 3, figs 6, 8). Because of the presence of some processes in all specimens observed, this species has been included in Spiniferites.

\section{Genus Tuberculodinium Wall, 1967}

Tuberculodinium $\mathrm{sp}$.

(Pl. 2, figs 10-11)

Dimensions. Range of eight specimens - central body diameter 75-90 $\mu \mathrm{m}$; length of processes: up to $15 \mu \mathrm{m}$.

Occurrence. Cerro Águila section, CA1-CA3; Río Candelaria section, RC2-RC5.

Remarks. Tuberculodinium sp. differs from described species of the genus in that most of its processes have a quadrangular cross-section and support a fibroid ectophragm. Though it was not possible to assess the number and distribution of processes, some appear to be pre- and postcingular, and some appear to be cingular and apical. 

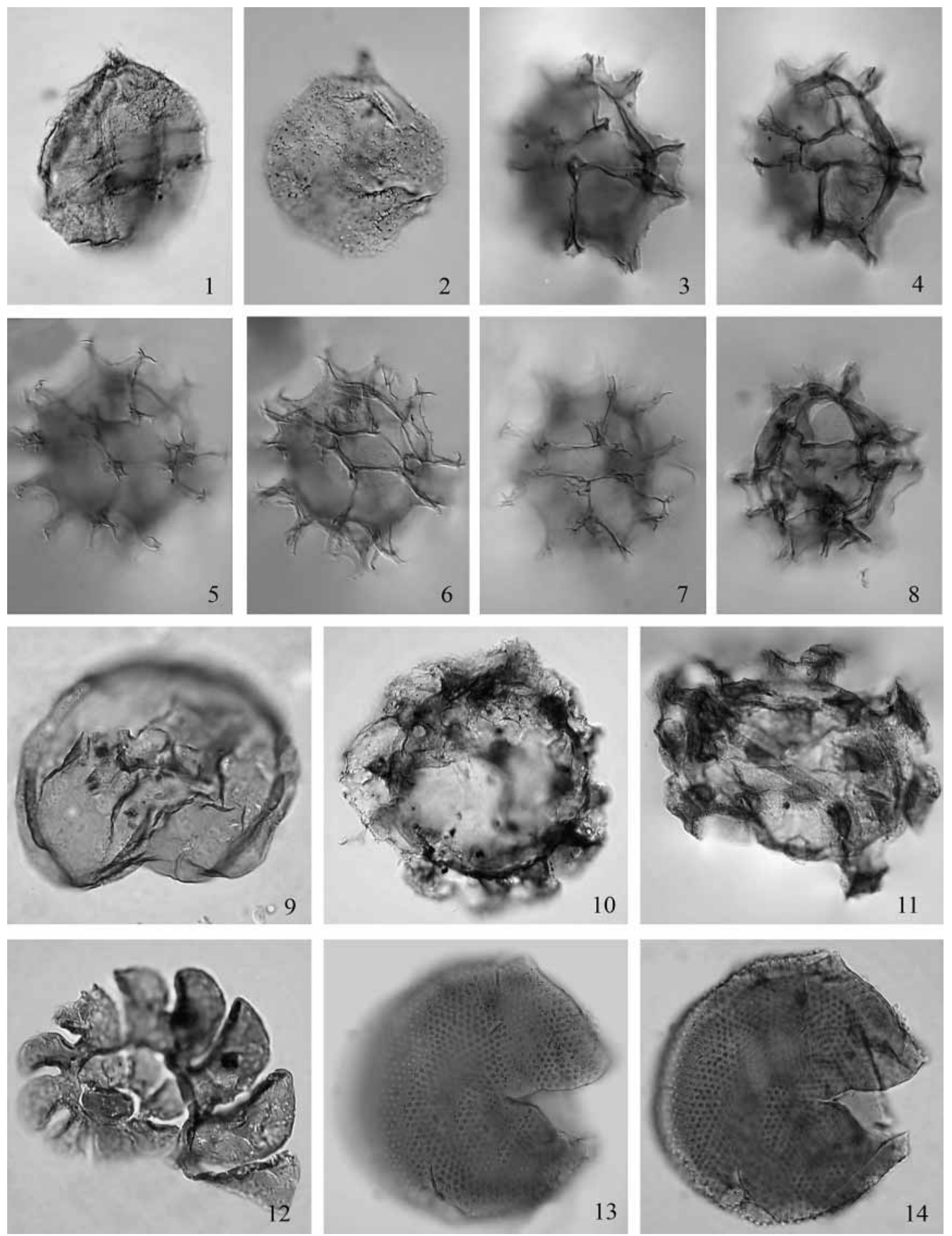

Explanation of Plate 2.

fig. 1. Phthanoperidinium echinatum: LPUNS-CP4; P36655 (1); 48.3/101.2; P49/3; width $38 \mu \mathrm{m}$; high focus. fig. 2. Vozzhennikovia cearaichia: LPUNS-CP3; P36652 (1); 37.5/106.6; J38/4; width 37 mm; right lateral view, high focus. figs 3-4. Spiniferites scalenus: LPUNS-CA1; P36662 (1); 48/108; H49/3; central body width $38 \mu \mathrm{m}$; left lateral dorsal view - 3, high focus, 4, intermediate focus. figs 5-6. Spiniferites scalenus: LPUNS-CA3; P36660 (1); 43.5/104.5; M44/1; central body width $37 \mu \mathrm{m}$; oblique left lateral view - 5, high focus on the crests and processes, $\mathbf{6}$, low focus showing the archaeopyle. fig. 7. Spiniferites scalenus: LPUNS-CA1; P36662 (1); 49.5/109.5; G50/4; central body width $35 \mu \mathrm{m}$; lateral view, high focus. fig. 8. Spiniferites scalenus: LPUNS-CA1; P36662 (1); 505/94.5; $\times 51 / 2$; central body width $35 \mu \mathrm{m}$; dorsal view, high focus. fig. 9. Selenopemphix nephroides: LPUNS-RC5; 58/99 (1); 36.1/105.7; K37/3; width $75 \mu \mathrm{m}$; apical view, intermediate focus. fig. 10. Tuberculodinium sp.: LPUNS-RC4; 57/99 (1); 28.3/98.7; S28/0; width $75 \mu \mathrm{m}$; antapical view, high focus. fig. 11. Tuberculodinium sp.: LPUNS-CA1; P36662 (1); 39.6/113.5; C40/1; width 80 $\mu$ m; lateral view, high focus. fig. 12. Foraminiferal lining: LPUNS-RC4; 57/99 (1); 27/97.3; T27/3; total width 78 m. figs 13-14. Prasinophycean algae: LPUNS-RC6; 59/99 (1); 25.5/96.8; U25/2; diameter $100 \mu \mathrm{m}$ - 13, high focus, 14, intermediate focus. 

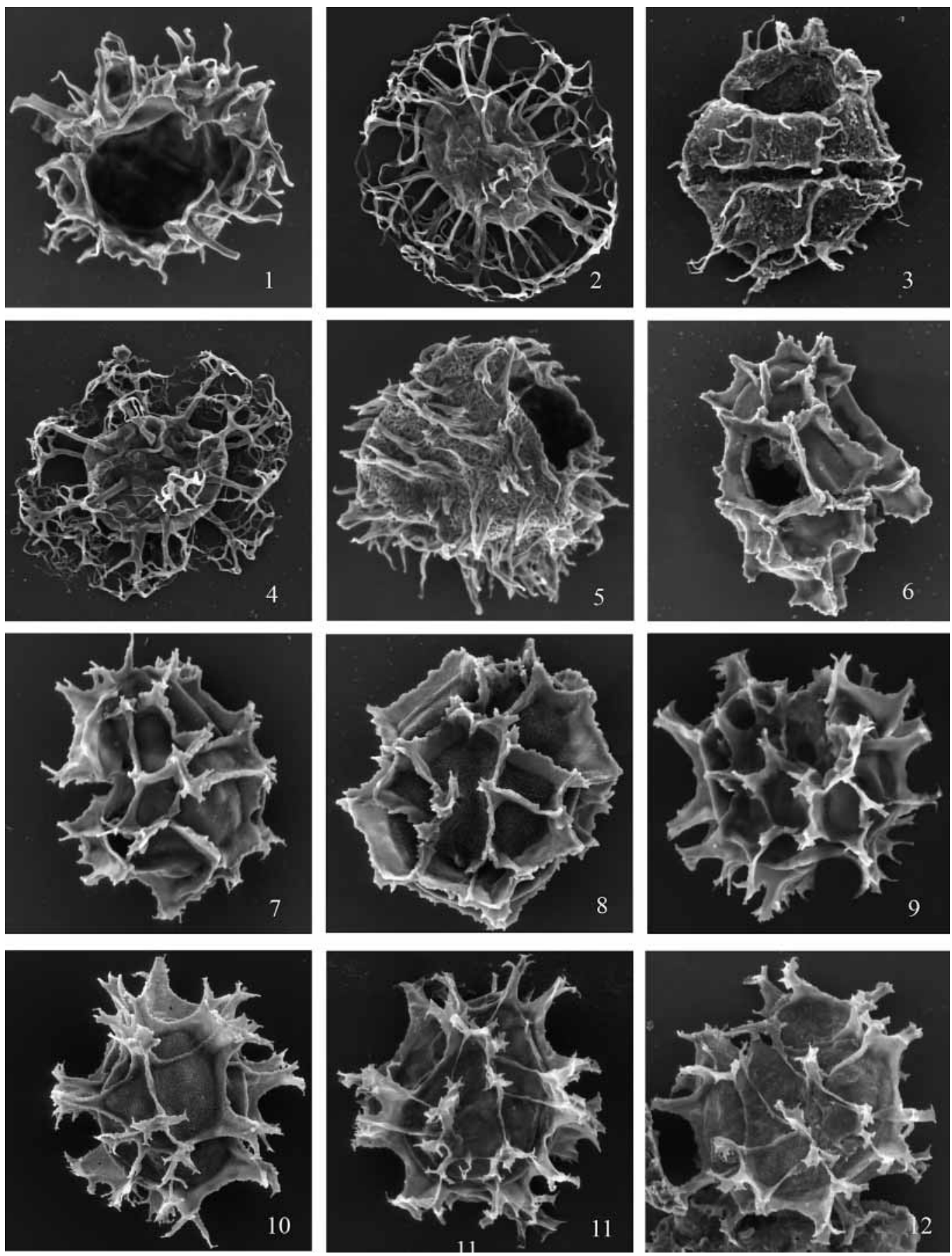

Explanation of Plate 3.

Scanning electron photomicrographs. The specimens illustrated here are curated in the National Collection of Type Invertebrate and Plant Fossils, Geological Survey of Canada, 601 Booth Street, Ottawa, Ontario, Canada K1A OE8 (at the time of writing on long-term loan to the GSC Atlantic, Bedford Institute of Oceanography, Dartmouth, Nova Scotia, Canada B2Y 4A2). The species name is followed by the section designation, the sample number and then the National Collection ('GSC') number; further supplemental information follows that. fig. 1. Cleistosphaeridium diversispinosum: CA3; P36660; GSC 34680; central body width 48 um; apical view. fig. 2. Nematosphaeropsis lemniscata: CA4; P36659; GSC 34681; central body width $37 \mu \mathrm{m}$. fig. 3. Phthanoperidinium comatum: CA3; P36660; GSC 34682; central body width $55 \mu \mathrm{m}$; dorsal view. fig. 4 . Reticulatosphaera actinocoronata: CA3; P36660; GSC 34683; central body width 33 um. fig. 5. Operculodinium centrocarpum: CA3; P36660; GSC 34684; central body width $40 \mu \mathrm{m}$; left lateral view. fig. 6. Spiniferites scalenus: CA3; P36660; GSC 34685; central body width $35 \mu \mathrm{m}$; oblique dorsal view. fig. 7. Spiniferites scalenus: CA4; P36659; GSC 34686; central body width 35 um; lateral view. fig. 8. Spiniferites scalenus: CA4; P136659; GSC 34687; central body width $38 \mu \mathrm{m}$; ventral view. fig. 9. Spiniferites scalenus: CA4; P36659; GSC 34688; central body width $40 \mu \mathrm{m}$. fig. 10. Spiniferites scalenus: CA4; P136659; GSC 34689; central body width 36 um. fig. 11. Spiniferites scalenus: CA3; P136660; GSC 34690; central body width 35 um; ventral view. fig. 12. Spiniferites scalenus: CA3; P136660; GSC 34691; central body width $38 \mu \mathrm{m}$; ventral view. figs $6-12$ show specimens with crests of variable height. 
Genus Vozzhennikovia Lentin \& Williams, 1976

Vozzhennikovia sp.

(Pl. 4, figs 10-11)

Occurrence. Río de la Turba section, R1-R6, R10.

Remarks. This species of Vozzhennikovia closely resembles $V$. apertura. However, in most of the specimens here, the archaeopyle involves not only the $2 \mathrm{a}$ plate but also the $1 \mathrm{a}$ and $3 \mathrm{a}$ plates.

\section{PALYNOSTRATIGRAPHY}

\section{La Despedida Formation}

Figure 3 shows the distribution of dinocyst species in the lower member of the La Despedida Formation in the Río de la Turba section. In this section, the La Despedida Formation cannot be older than Middle Eocene (Lutetian-Bartonian) because of the consistent and common occurrence of Enneadocysta dictyostila throughout the section. Enneadocysta dictyostila was first described by Menéndez (1965) from Eocene-Oligocene deposits of Tierra del Fuego. Other authors mistakenly assigned specimens of this species to Areosphaeridium diktyoplokum, a species described by Klumpp (1953) from the Eocene of Germany (Fensome et al., 2007). Areosphaeridium diktyoplokum has one process on the single antapical plate, whereas Enneadocysta has two. Stover \& Williams (1995) erected Enneadocysta partridgei to include those specimens from the Southern Hemisphere, which had been mistakenly assigned to Areosphaeridium diktyoplokum and gave its first occurrence as Bartonian. Fensome et al. (2007) considered Enneadocysta dictyostila to be the taxonomic senior synonym of Enneadocysta partridgei. Brinkhuis et al. (2003a), based on calibrated information from ODP site 1172 (East Tasman Plateau), assigned an age of $48.8 \mathrm{Ma}$ to the first common occurrence of Enneadocysta dictyostila.

Constraints to allow delineation of the minimum age of the lower member of the La Despedida Formation are more difficult to find. Because of the presence of Hystrichosphaeridium tubiferum, the lower part of the section (RT1 to RT5) is considered to have a minimum middle Lutetian age. According to Williams et al. (2004), this species has its LO in Northern Hemisphere mid-latitudes at $47 \mathrm{Ma}$ (based on Bujak \& Mudge, 1994). Arachnodinium antarcticum (Pl. 5, figs 1-2; first occurrence, FO: $51.4 \mathrm{Ma}$; last occurrence, LO: $38.8 \mathrm{Ma}$; Williams et al., 2004) occurs in most of the samples up to RT7, confirming a Middle Eocene (Lutetian-Bartonian) age for most of the section. Hystrichosphaeridium truswelliae, which is present throughout the section, has its LO at $39 \mathrm{Ma}$, according to Brinkhuis et al. (2003a). It would appear to be a useful index species but occurs consistently in all three of the Cabo Peña sections. These sections also contain Reticulatosphaera actinocoronata, Nematosphaeropsis lemniscata and Phthanoperidinium echinatum. Since Reticulatosphaera actinocoronata has a first occurrence of $33.5 \mathrm{Ma}$ in high latitudes and 35.3 in mid latitudes (Brinkhuis et al., 2003a, b), it is assumed that the true LO of H. truswelliae is within the Priabonian, indicating a Bartonian minimum age. The presence of Turbiosphaera filosa (FO: 71.3 Ma; LO: $37 \mathrm{Ma}$; Williams et al., 1998) and Pyxidinopsis delicata (Early to Middle Eocene, according to Wilson, 1988) are supporting evidence for a Lutetian-Bartonian age. However, a more definitive age for the upper part of the Río de la Turba section cannot be determined, except to conclude that it is within the Eocene. One possible clue is the presence of Glaphyrocysta spp., which is relatively uncommon in post-Middle Eocene rocks from offshore eastern Canada. However, that is too tenuous to be definitive.

A few specimens of Odontochitina sp., Manumiella sp., Isabelidinium sp., Oligosphaeridium complex, Sepispinula ancorifera and Xenascus sp. were recorded in this section. These species represent reworked material from Upper Cretaceous deposits.

\section{Cabo Peña Formation}

Figure 4 shows the distribution of dinocyst species in the Cabo Peñas section. Most of the species are long ranging and are common in Palaeogene deposits world-wide. The presence of Reticulatosphaera actinocoronata, Gelatia inflata and Nematosphaeropsis lemniscata at the base indicates an age no older than Priabonian (Late Eocene). As noted above, Reticulatosphaera actinocoronata has a first occurrence of $33.5 \mathrm{Ma}$ in high latitudes and $35.3 \mathrm{Ma}$ in mid latitudes (Brinkhuis et al., 2003a, b, respectively). Brinkhuis et al. (2003a) and Sluijs et al. (2003) suggested a Magnetochron C16 base for this species, which would place it at about $36 \mathrm{Ma}$. Brinkhuis et al. (2003a) indicated that Gelatia inflata had its first occurrence at the same horizon in ODP Leg 189 sites off Tasmania.

Brinkhuis et al. (2003b) gave a LO for Deflandrea convexa at 35.8 Ma, within the Priabonian. The presence of a few specimens of this species in samples CP3 and CP4 might constrain the age of the middle part of the section to the early Priabonian.

Nematosphaeropsis lemniscata has not been recorded below the Eocene-Oligocene boundary in the Northern Hemisphere (Williams et al., 1998). However, this species occurs at the base of the Cabo Peñas section, with other dinocysts that have their LOs within the Late Eocene. Thus, it is reasonable to conclude that the FO of Nematosphaeropsis lemniscata might be within the Priabonian in the Southern Hemisphere.

Stover \& Williams (1995) and Williams et al. (2004) considered Enneadocysta dictyostila (as Enneadocysta partridgei) to have a LO in the Rupelian (about $31 \mathrm{Ma}$ ). However, Sluijs et al. (2003) noted that the consistent LO of E. partridgei at different sites from ODP Leg 189, offshore Tasmania, does not extend into the Early Oligocene. They suggested that the rare occurrence of E. partridgei in the Early Oligocene represents reworking. Archangelsky (1969) believed E. dictyostila (as Cordosphaeridium diktyoplokum) was probably reworked in the upper part of the Río Turbio Formation of southwest Santa Cruz Province, Argentina. Malumián (2002, chart 1), regarded the upper part of the Río Turbio Formation as early Rupelian. Stickley et al. (2004) indicated a last (abundant) occurrence for Enneadocysta spp. in ODP 1172A core at the top of Magnetochron $\mathrm{C} 13 \mathrm{n}$ (about $33.5 \mathrm{Ma}$ ), extending this event into the earliest Oligocene. Based on the above, the age of the Cabo Peña Formation at its type locality is interpreted as being no younger than earliest Oligocene.

Dinocyst distribution in the Cerro Águila section is shown in Figure 5. The presence of Reticulatosphaera actinocoronata and Gelatia inflata at the base indicates a maximum Priabonian age. Based on the above discussion on Enneadocysta dictyostila, the 

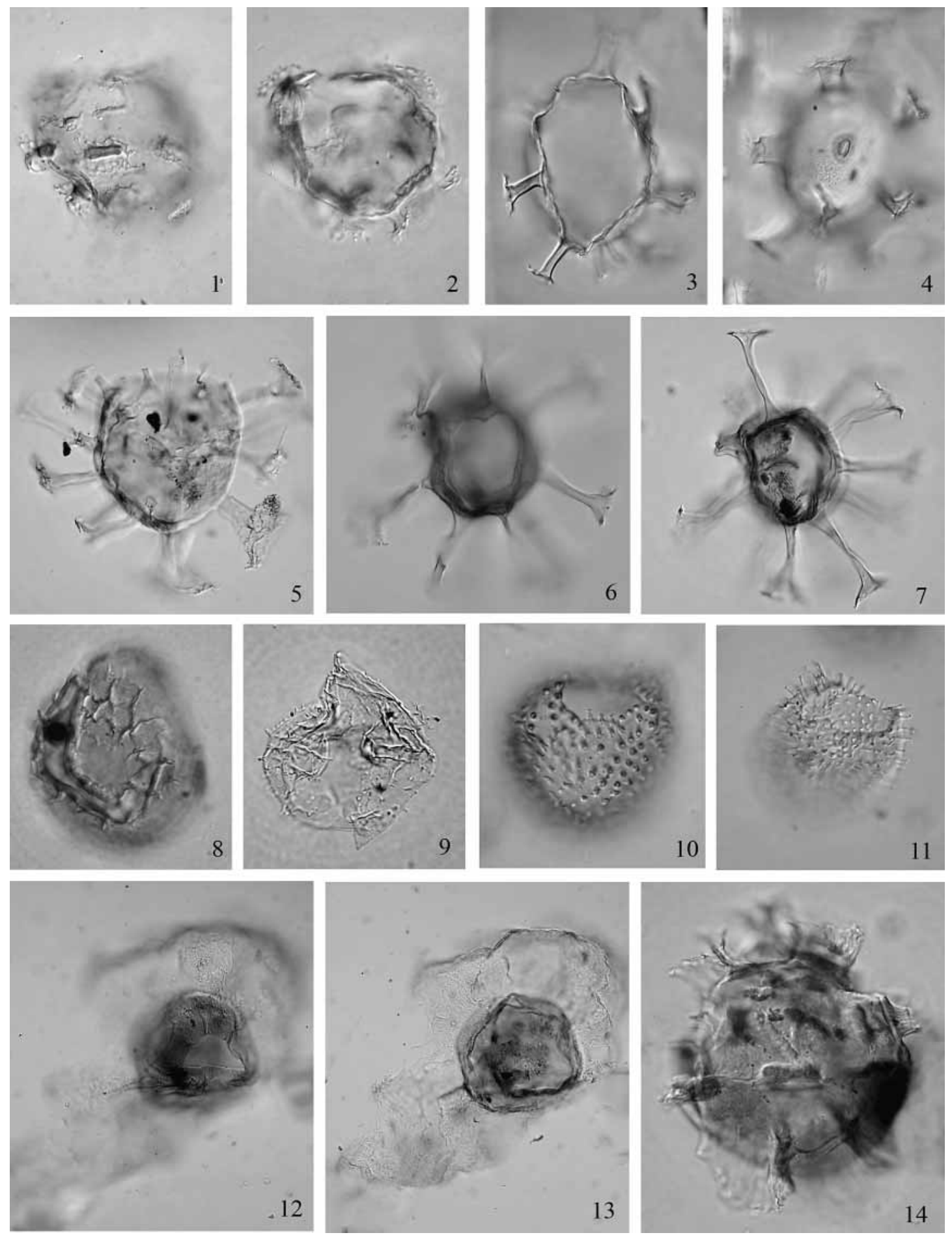

Explanation of Plate 4.

figs 1-2. Enneadocysta brevistila: LPUNS-RT4; $34 / 99$ (1); 46/105; L46/4; central body width 50 $\mu$ m; orientation unknown - 1, high focus, 2, low focus. figs 3-4. Homotryblium abbreviatum: LPUNS-RT9; 39/99 (1); 39.7/105; L39/3; central body width 40 um; apical view - 3, high focus, 4, low focus. fig. 5. Hystrichosphaeridium truswelliae: LPUNS-RT3; 33/99 (1); 39.5/104; N40/1; central body width $45 \mu$ m; intermediate focus. figs 6-7. Hystrichosphaeridium tubiferum: LPUNS-RT1; $31 / 99$ (1); 42.2/112; D43/3; central body width $40 \mu \mathrm{m}$; apical view - 6, high focus, 7, intermediate focus. fig. 8. Pyxidinopsis delicata: LPUNS-RT2; 32/99 (1); 41.5/109; G42/3; central body width $37 \mu$ m; intermediate focus. fig. 9. Spinidinium sp.: LPUNS-RT4; 34/99 (1); 37/95; V37/3-4; central body width $50 \mu \mathrm{m}$; high focus. fig. 10. Vozzhennikovia sp.: LPUNS-RT6; 36/99 (1); 37/94; $\times 37 / 0$; central body width $35 \mu \mathrm{m}$; dorsal view, high focus on process and archaeopyle. fig. 11. Vozzhennikovia sp.: LPUNS-RT3; 33/99 (1); 44/108.5; H44/2; central body width $42 \mu \mathrm{m}$; lateral view, high focus showing the 3I archaeopyle. figs 12-13. Thalassiphora pelagica: LPUNS-RT4; 34/99 (2); 24.2/104.9; M24/1; central body width $75 \mu \mathrm{m}$; dorsal view - 12, high focus showing the archaeopyle, 13, intermediate focus. fig. 14. Turbiosphaera filosa: LPUNS-RT3; 33/99 (1); 35.8/101.3; R33/3; central body width $60 \mu \mathrm{m}$; right lateral view, intermediate focus. 


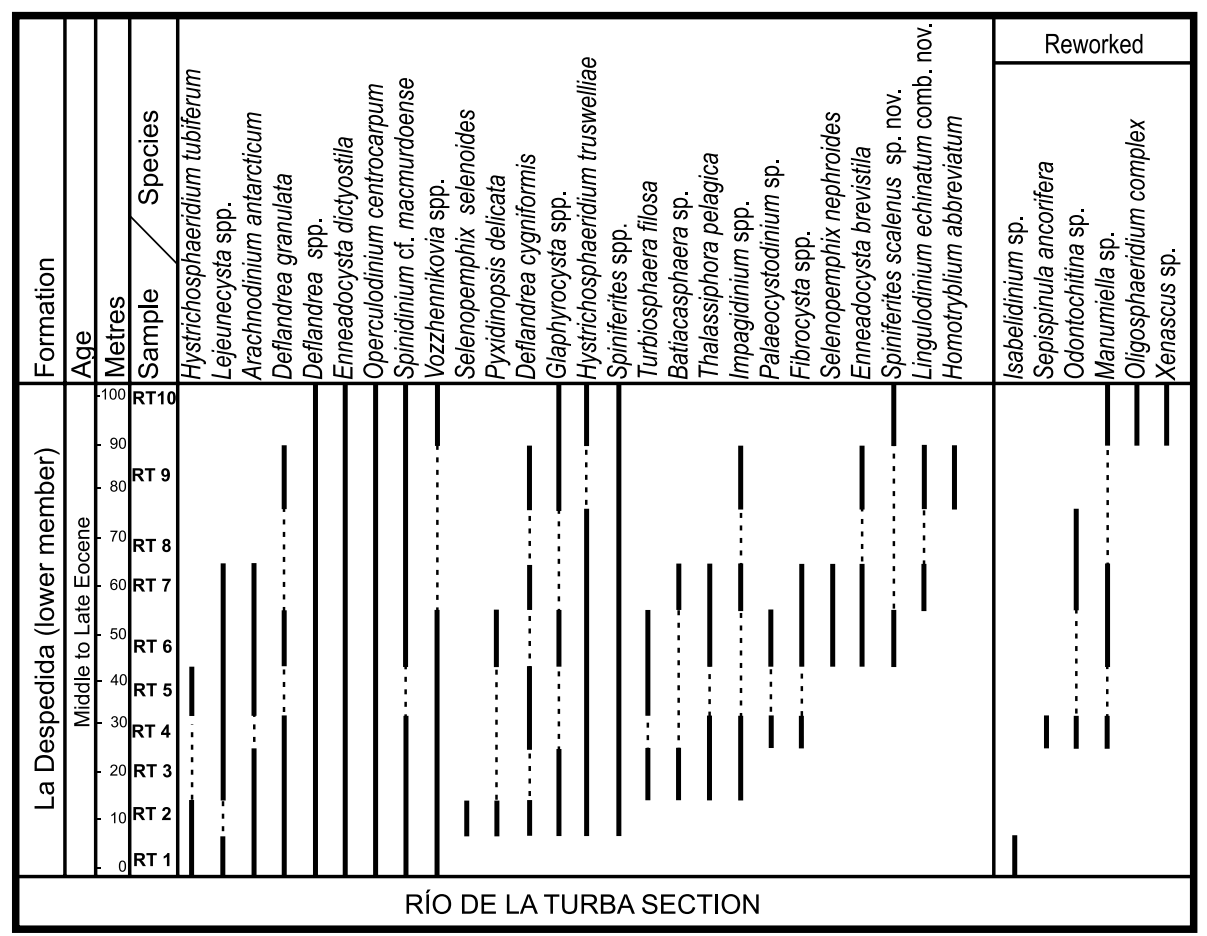

Fig. 3. Stratigraphical distribution of dinocyst species from the lower member of the La Despedida Formation at the Río de la Turba section.

uppermost part of the Cabo Peña Formation is interpreted to be close to the Eocene/Oligocene transition. The stratigraphical ranges of Batiacasphaera compta (FO: $38 \mathrm{Ma}$; LO: $33.7 \mathrm{Ma}$; Williams et al., 1998) and Phthanoperidinium comatum (FO: 45.7 Ma; LO: 30.7 Ma; Williams et al., 1998) are consistent with this age.

The biostratigraphy of the Río Candelaria section is derived solely from dinocyst assemblages (Fig. 6). As discussed previously, the presence of Reticulatosphaera actinocoronata and Gelatia inflata at the base, and Deflandrea convexa (with a LO at $35 \mathrm{Ma}$ ) in sample RC2, indicates a maximum Priabonian age. The upper part of the Cabo Peña Formation at Río Candelaria may extend into the Rupelian, based on the presence of Corrudinium incompositum, Deflandrea antarctica and Phthanoperidinium comatum, which have Los at $28.5 \mathrm{Ma}, 29.4 \mathrm{Ma}$ and 30.7 Ma respectively (Williams et al., 1998, 2004). Based on the presence of Enneadocysta dictyostila, however, the minimum age of the section is considered to be earliest Oligocene. As in the Cabo Peñas and Cerro Águila sections, Reticulatosphaera actinocoronata, Gelatia inflata and Nematosphaeropsis lemniscata co-exist with species whose LOs are close to the base of the Rupelian. This is taken to indicate an age close to the EoceneOligocene boundary for the Cabo Peña Formation in its type area. However, the resolution of these data does not allow precise correlation of the sections studied with the boundary.

The few specimens of Arachnodinium antarcticum in the Cerro Águila and Río Candelaria sections are interpreted as reworked, since its LO has been placed at 38.8 Ma (Brinkhuis et al., 2003a). Specimens of this species are probably derived from the lower member of the La Despedida Formation. The dinocyst assemblages from the Cabo Peñas section contain a few specimens of Glaphyrocysta retiintexta, Alisocysta margarita,
Oligosphaeridium complex and Hafniasphaera sp., which are probably from lower Palaeogene deposits. Likewise, specimens of Odontochitina costata and Manumiella sp. at Cerro Águila and Odontochitina sp. and Nelsoniella aceras at Río Candelaria are considered to be reworked from Upper Cretaceous rocks.

\section{PALAEOENVIRONMENT}

In the Río de la Turba section, the dinocyst assemblages include most of the species in the Antarctic-endemic 'Transantarctic flora' of Wrenn \& Beckman (1982): these are Arachnodinium antarcticum, Deflandrea antarctica, D. granulata, D. cygniformis and species of Spinidinium and Vozzhennikovia. Wellrepresented taxa include Hystrichosphaeridium tubiferum, $H$. truswelliae, species of Lejeunecysta, and Fibrocysta sp. Enneadocysta dictyostila was regarded as another component of the 'Transantarctic flora' by Truswell (1997) but has been recorded also from mid-latitudes - in the Punta del Este and Colorado Basins (Guerstein et al., 2003).

The lowermost palynological assemblage from the Río de la Turba section is characterized by low palynomorph abundances, with $26 \%$ of the palynomorphs being dinocysts. This percentage increases upwards to sample LT 5, then decreases to sample LT10. Even in samples where the dinocyst percentage is greater than $50 \%$, palynomorphs are sparse and species richness is low (Table 1; Fig. 7). The presence of several specimens of Deflandrea and other peridiniacean cysts (P-cysts) may reflect near-shore marine conditions (Brinkhuis, 1994; Pross \& Brinkhuis, 2005). Sluijs et al. (2005) suggested that high abundances of P-cysts of supposed heterotrophic habits (even though most of them have no living relatives), may indicate nutrientrich waters, probably derived from terrigenous input. However, RT5 to RT7 assemblages (Fig. 7) are dominated mainly by 

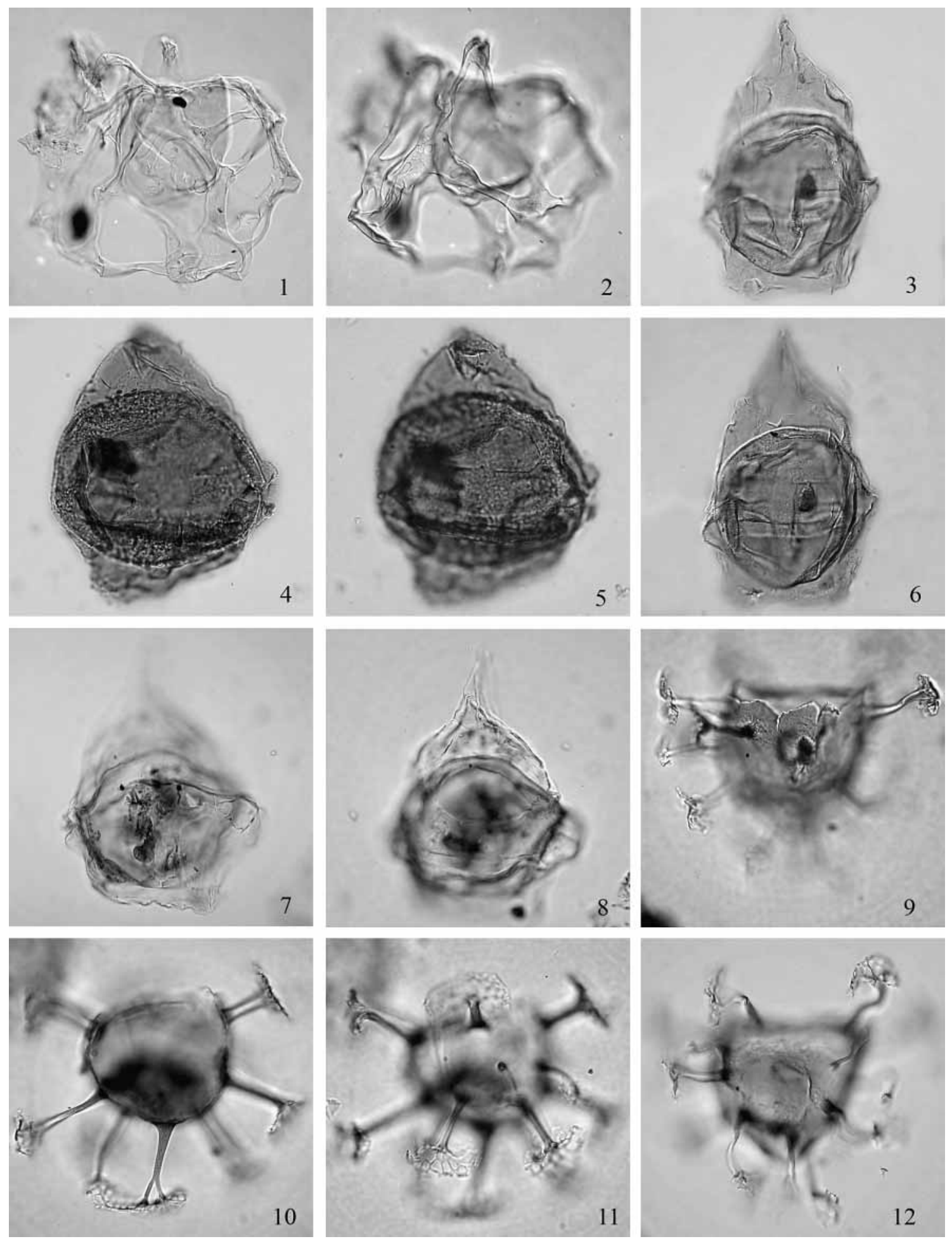

Explanation of Plate 5.

figs 1-2. Arachnodinium antarcticum: LPUNS-RT6; 1546 (2); 30.7/105.5; L31-1; orientation unknown; central body width 45 um, central body length $50 \mu \mathrm{m}-1$, high focus, 2 , low focus. figs 3, 6. Deflandrea antarctica: LPUNS-RT6; $36 / 99$ (1); 35.1/94; $\times 35 / 0$; central body width $60 \mu \mathrm{m}$; dorsal view - 3, dorsal surface, 6, ventral surface. figs 4-5. Deflandrea granulata: LPUNS-RT3; 33/99 (1); 33.4/98; S33/4; central body width 85 $\mu$; ventral view - 4, intermediate focus, 5, dorsal surface. figs 7-8. Deflandrea cygniformis: LPUNS-RT4; 34/99 (1); 38/106.3; K38/0; central body width 70 $\mu$; ventral view - 7, ventral surface, 8, dorsal surface. figs 9, 12. Enneadocysta dictyostila: LPUNS-RT4; 34/99 (1); 41.6/95.5; V42/0; central body width $53 \mu \mathrm{m}$; ventral view - 9, ventral surface showing the sulcal notch, 12, dorsal surface. figs 10-11. Enneadocysta dictyostila: LPUNS-RT9; 39/99 (1); 35/104.5; M35/0; central body width $44 \mu \mathrm{m}$; bright field - 10, intermediate focus, 11, low focus. 


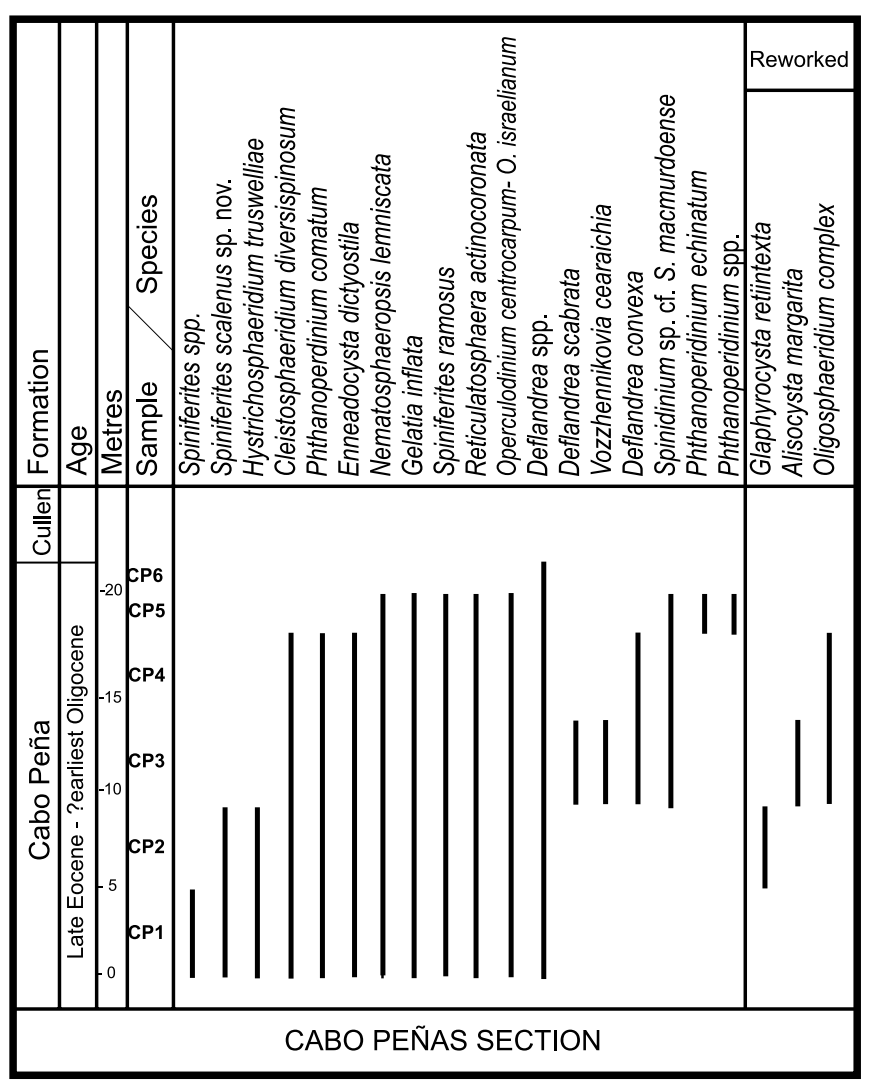

Fig. 4. Stratigraphical distribution of dinocyst species from the Cabo Peña Formation at the Cabo Peñas section.

Enneadocysta dictyostila. In dinocyst assemblages from ODP Leg 189, Site 1170, the Enneadocysta spp. maxima correlate with high $\mathrm{CaCO}_{3}$ content in sediments, possibly reflecting more offshore, less eutrophic marine conditions (Röhl et al., 2004)

A general transgressive-regressive event was observed in the Late Eocene-earliest Oligocene Cabo Peña Formation. This is based on the decrease in dinocyst percentages of the total palynomorphs toward the top of the three sections. Common occurrences of outer neritic to oceanic markers throughout the Cabo Peñas section, however, suggest open-water conditions (Table 2; Fig. 8). The authors agree with Pross \& Brinkhuis (2005) and Sluijs et al. (2005) that Nematosphaeropsis lemniscata, Reticulatosphaera actinocoronata and Impagidinium spp. are offshore taxa. However, in the Cerro Águila section the regressive trend is steeper than in Cabo Peñas, with the best representation of outer neritic and oceanic species in the lower part of the section (Table 3; Fig. 9). In the upper part of the Cerro Águila section, Cleistosphaeridium diversispinosum, Deflandrea spp., Enneadocysta spp. and protoperidiniaceans have their maximum frequencies. All these taxa are considered to have inhabited coastal palaeoenvironments (Brinkhuis, 1994; Pross \& Brinkhuis, 2005; Sluijs et al., 2005).

The Río Candelaria dinocyst assemblages indicate a change from inner neritic at the bottom to coastal marine conditions in the middle part of the section (Table 4; Fig. 10). Common protoperidiniaceans (Brigantedinium? spp., Selenopemphix nephroides and Lejeunecysta spp.) are characteristic of cold, nutrient-rich waters, related to inner neritic environments (e.g.

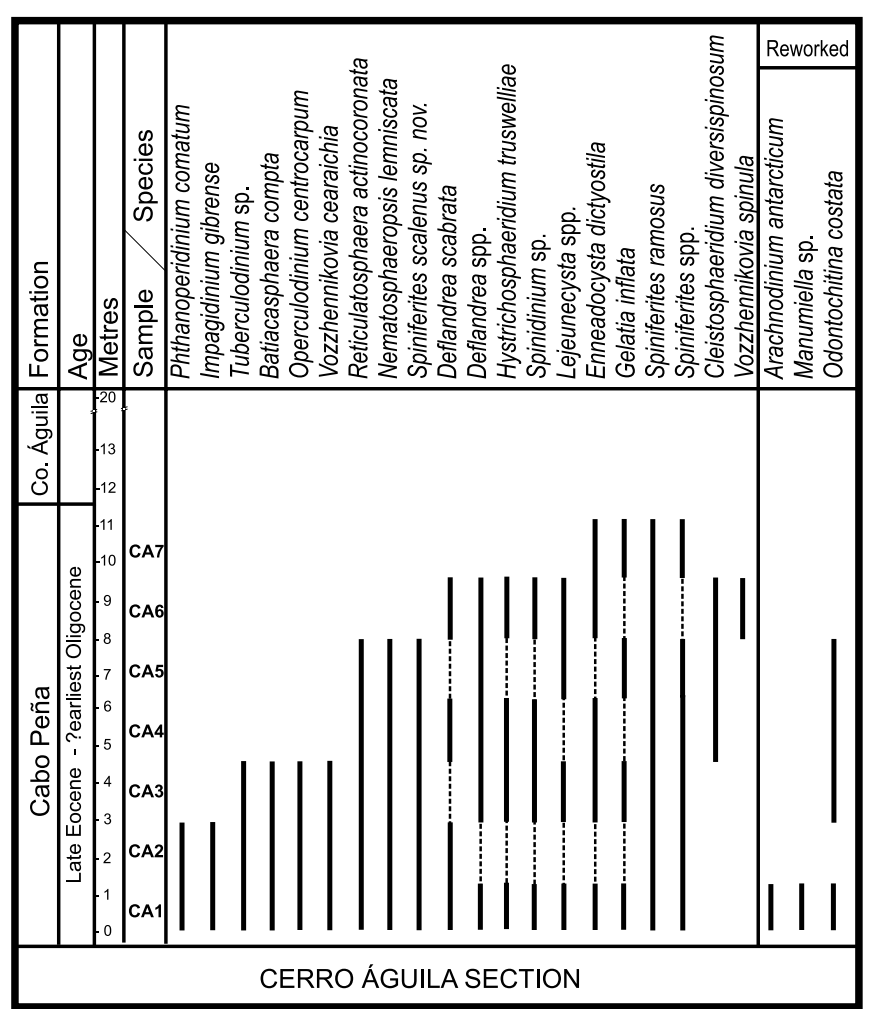

Fig. 5. Stratigraphical distribution of dinocyst species from the Cabo Peña Formation at the Cerro Águila section.

Head et al., 1989a, b; Edwards \& Andrle, 1992; Head \& Westphal, 1999). Species of Deflandrea, Enneadocysta, Operculodinium and Tuberculodinium are considered restricted marine to coastal taxa according to Pross \& Brinkhuis (2005). Assemblages from the upper part of the section are dominated by Operculodinium spp. and Spiniferites spp., and have high percentages of sporomorphs and green algae (hydrodictyaceans and prasinophyceans), reflecting marginal marine conditions.

Several of the dinocyst species are viable palaeoclimatic markers. For example, Gelatia inflata indicates cool water and high latitudes, based on its common occurrences in the North Pacific Ocean, in the Bering Sea and over the Tasman Plateau (Bujak, 1984; Head \& Norris, 1989; Brinkhuis et al., 2003a, respectively). Based on observations from central Italy, Brinkhuis \& Biffi (1993) considered the migration of this species into lower latitudes at the Eocene-Oligocene transgression to reflect cooling episodes.

Comparison of the La Desperido assemblages at Río de la Turba (Fig. 7) with those from three Cabo Peña assemblages (Figs 8-10) shows that neither the high dominance of the typical 'Transantarctic flora' (sensu Wrenn \& Beckman, 1982) nor the Enneadocysta spp. peaks occur in the latter. The Cabo Peña assemblages contain common protoperidiniacean cysts, supposedly produced by heterotrophic dinoflagellates that inhabited cool surface waters rich in dissolved nutrients. These components may indicate increasing terrestrial input, or may reflect the development of an upwelling system related to the incipient Antarctic Circumpolar Current.

Codignotto \& Malumián (1981) suggested an outer shelf depositional environment for the lower part of the Cabo Peña 


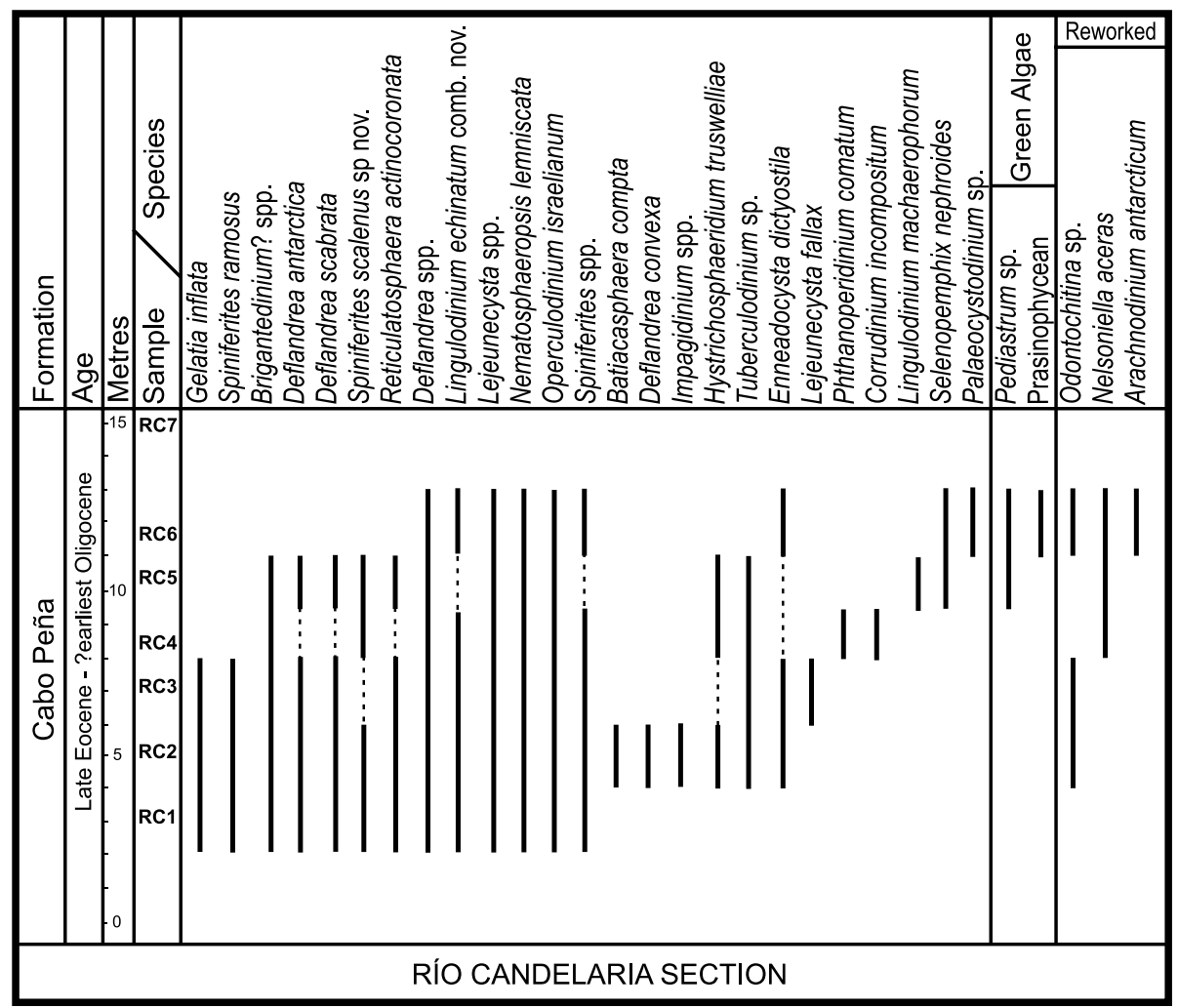

Fig. 6. Stratigraphical distribution of dinocyst species from the Cabo Peña Formation at the Río Candelaria section.

\begin{tabular}{|c|c|c|c|c|c|c|c|c|c|c|c|c|c|c|c|c|c|c|c|c|c|c|c|c|c|c|c|c|c|c|c|c|}
\hline Samples & 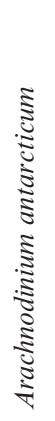 & 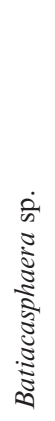 & 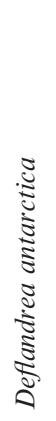 & 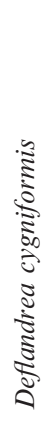 & 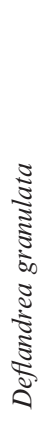 & 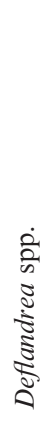 & 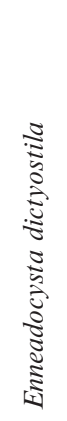 & 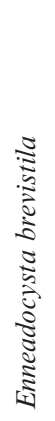 & 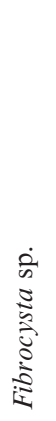 & 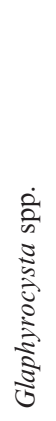 & 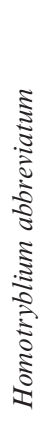 & 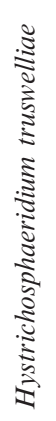 & 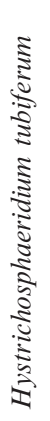 & 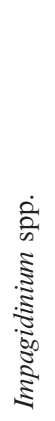 & 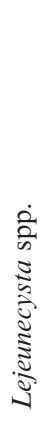 & 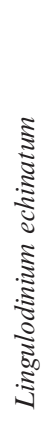 & 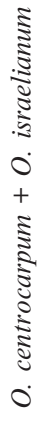 & 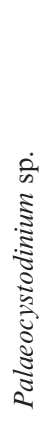 & 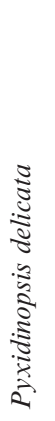 & 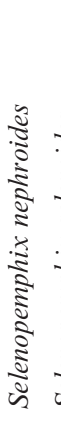 & 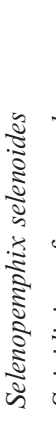 & 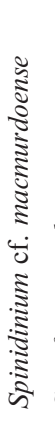 & 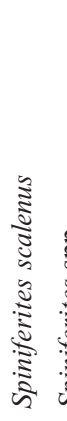 & 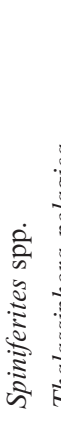 & 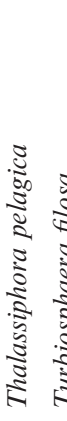 & 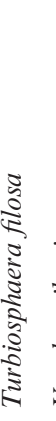 & 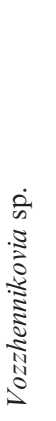 & 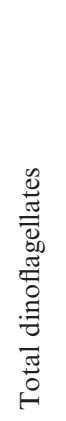 & 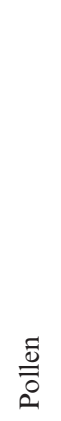 & 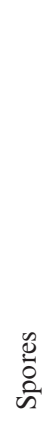 & 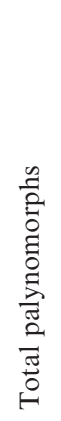 & 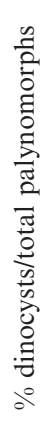 \\
\hline T 10 & & & & & & 8 & 9 & & 7 & 2 & & 12 & & & & & 5 & & & & & & 2 & 5 & & & 5 & 55 & 72 & 4 & 201 & 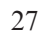 \\
\hline Г 9 & & & & 2 & 4 & 55 & 17 & 7 & 14 & 6 & 2 & 35 & & 4 & & 3 & 7 & & & & & 3 & & 7 & & & & 226 & 128 & 74 & 428 & 53 \\
\hline$\Gamma 8$ & & & & & & 7 & & & & & & & & & & & & & & & & 1 & & 1 & & & & $\mathrm{nc}$ & & & $\mathrm{nc}$ & $\mathrm{nc}$ \\
\hline 13 & 5 & 2 & & & 3 & 68 & 84 & & 2 & 2 & & 10 & & 2 & 2 & & 5 & & & & & 2 & & 6 & $1 \quad 1$ & 1 & 5 & 200 & 0 & 25 & 335 & 60 \\
\hline RT 2 & 3 & & & 3 & 5 & 5 & 94 & & & 1 & & 6 & 3 & & & & 10 & & 1 & & 1 & 1 & & 3 & & & 19 & 200 & 3 & 10 & 18 & 63 \\
\hline RT 1 & 2 & & & & 6 & 10 & 2 & & & & & & 8 & & 6 & & 10 & & & & & 6 & & & & & 9 & 59 & 141 & 23 & 213 & 26 \\
\hline
\end{tabular}

Table 1. Dinocyst distribution within samples from the lower member of the La Despedida Formation at Río de la Turba section (raw data)

Formation type section. Towards the upper part of the formation, they found a decrease in deep-water benthic foraminifera. Malumián \& Caramés (1989) recognized cool water assemblages including some of the same species that inhabit present-day subantarctic waters.

\section{DISCUSSION}

The 'Transantarctic flora' associated with Enneadocysta dictyostila peaks (usually recorded as Areosphaeridium diktyoplokum or E. partridgei) has been recorded mainly in Middle Eocene sections from Southern Hemisphere high latitudes. Such records 


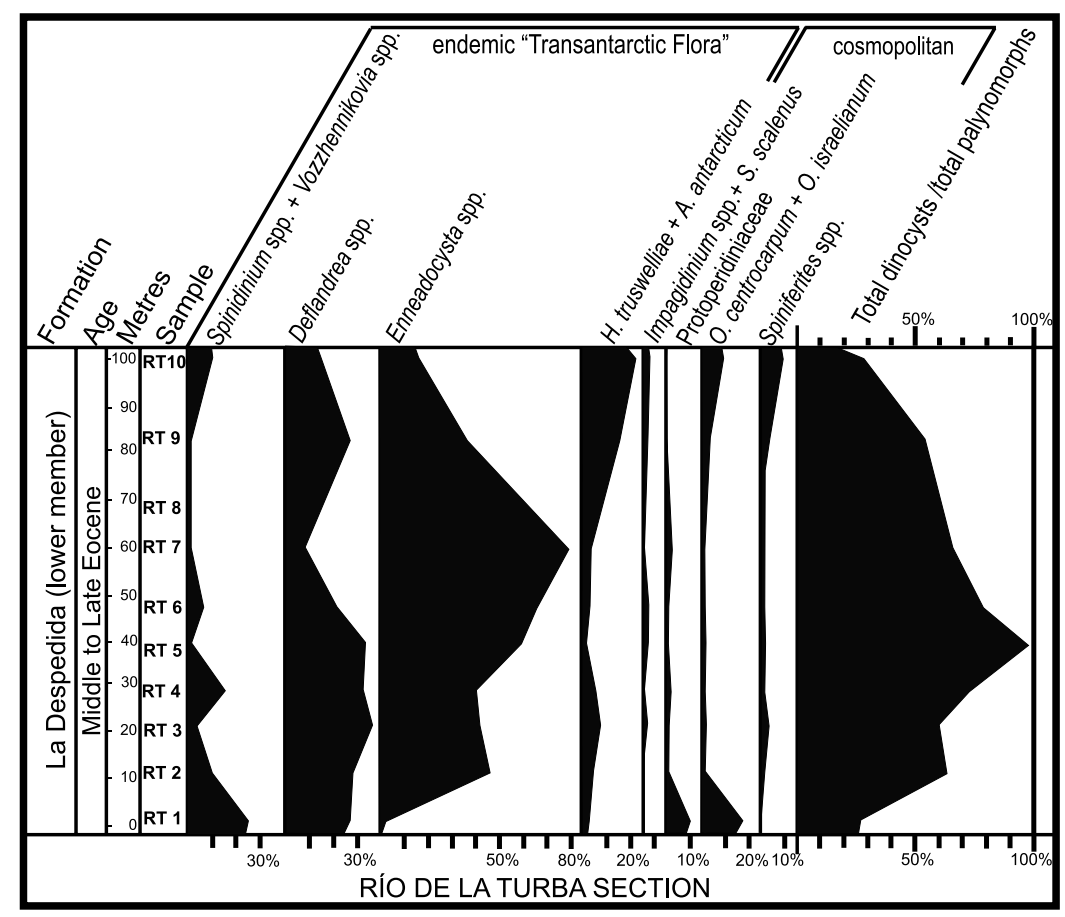

Fig. 7. Quantitative distribution of selected dinocyst groups within samples from the lower member of the La Despedida Formation at Río de la Turba section. The graph at the right shows ratio of dinocysts/total of palynomorphs.

\begin{tabular}{|c|c|c|c|c|c|c|c|c|c|c|c|c|c|c|c|c|c|c|c|c|c|c|c|c|c|c|c|}
\hline Samples & 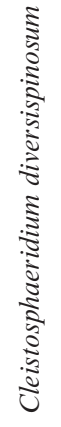 & 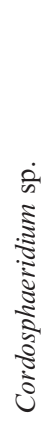 & 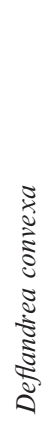 & 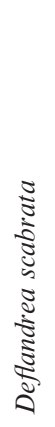 & 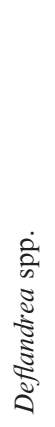 & 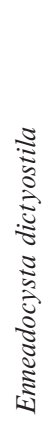 & 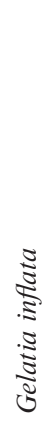 & 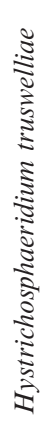 & 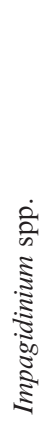 & 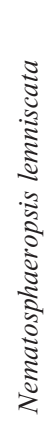 & 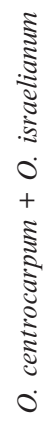 & 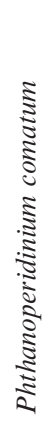 & 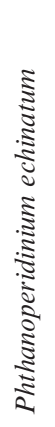 & 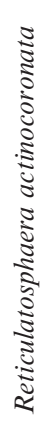 & 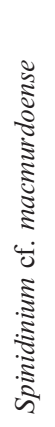 & 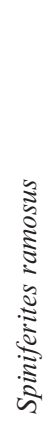 & 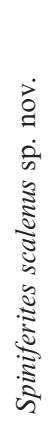 & 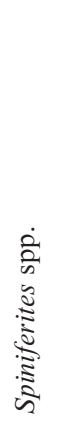 & 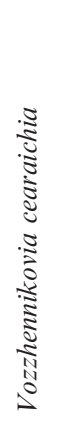 & 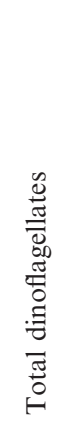 & $\begin{array}{l}\frac{\overline{0}}{\overline{0}} \\
\stackrel{0}{2}\end{array}$ & 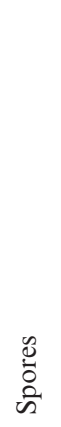 & 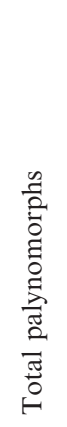 & 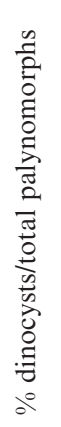 & 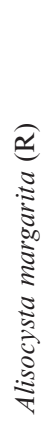 & 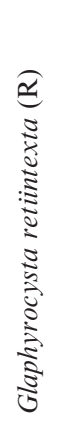 & 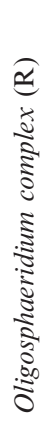 \\
\hline & & & & & 4 & & & & & & & & & & & & & & & & & & & & & & \\
\hline 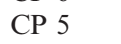 & & & & & 38 & & & & & 8 & & & 3 & 10 & 17 & & & & & & & & & & & & \\
\hline 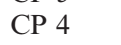 & 3 & 2 & 5 & & 8 & 17 & 3 & & & 1 & 5 & 4 & & 8 & & 17 & & & & 20 & & & & & & & \\
\hline
\end{tabular}

Table 2. Dinocyst distribution within samples from the Cabo Peña Formation at the Cabo Peñas section (raw data)

include: Archangelsky (1969), in the lower part of the Rio Turbio Formation, southern Argentina; Haskell \& Wilson (1975) in the DSDP Leg 29, off southeastern Australia and western New Zealand; Cocozza \& Clarke (1992) from the upper part of La Meseta Formation in northern Seymour Island; Mao $\&$ Mohr (1995) in a core from Brunce Bank in the Scotia Sea, off Antarctica; and the already mentioned records from ODP Leg 189, off Tasmania (Brinkhuis et al., 2003a, b; Sluijs et al., 2003). Using fully coupled, climate model simulations, Huber et al. (2004) demonstrated that clockwise system gyres were responsible for cooling the atmosphere; they proposed a 'cold trap' mechanism that would have removed the cold-intolerant taxa in the Southern Ocean during the Mid-Eocene.

Fensome et al. (2007) interpreted Enneadocysta as an areoligeracean (gonyaulacinean) rather than a cladopyxiinean dinocyst. Thus, it seems reasonable to conclude that the motile stage of Enneadocysta was autotrophic and that species of this genus preferred relatively warmer waters. On this basis, a relationship is suggested between the Enneadocysta peaks observed in the Río de la Turba section and the three other sites mentioned 


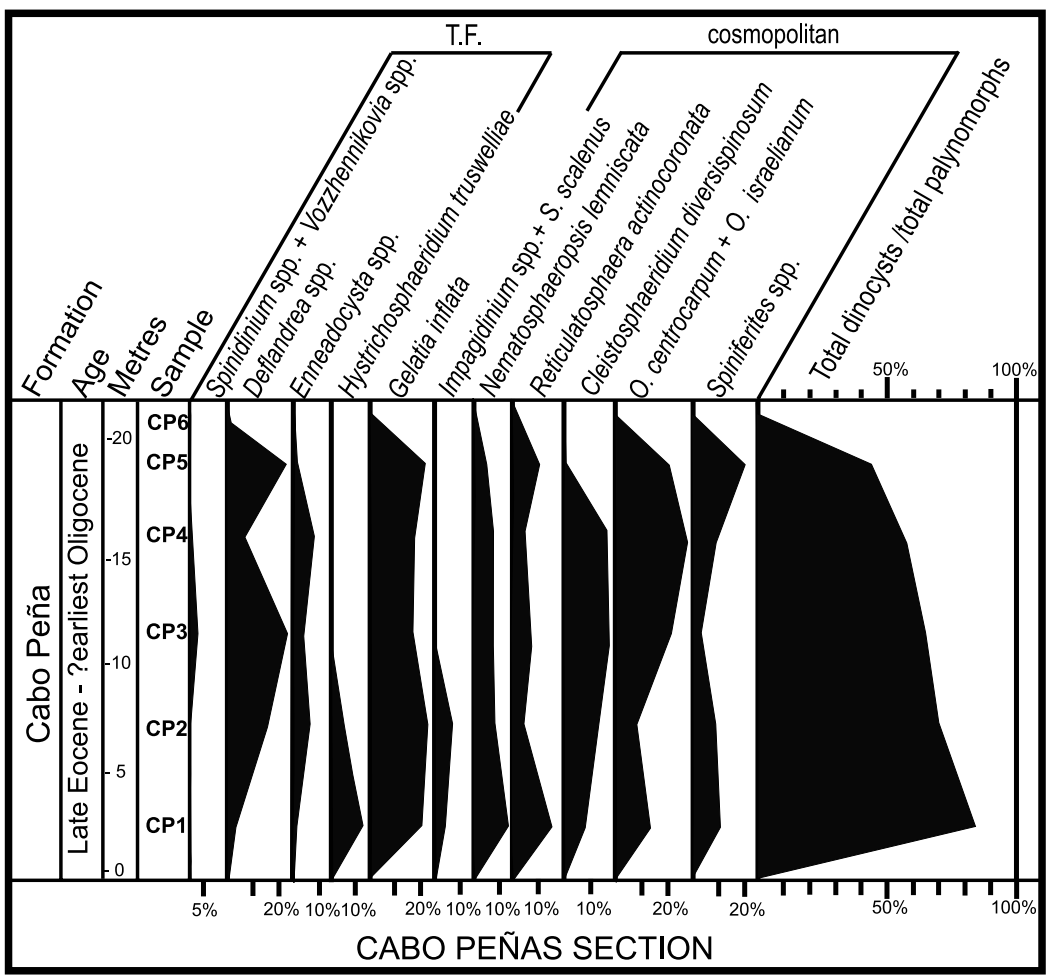

Fig. 8. Quantitative distribution of selected dinocyst groups within samples from the Cabo Peña Formation at the Cabo Peñas section. The graph at the right shows ratio of dinocysts to total of palynomorphs. T.F., endemic 'Transantarctic Flora'.

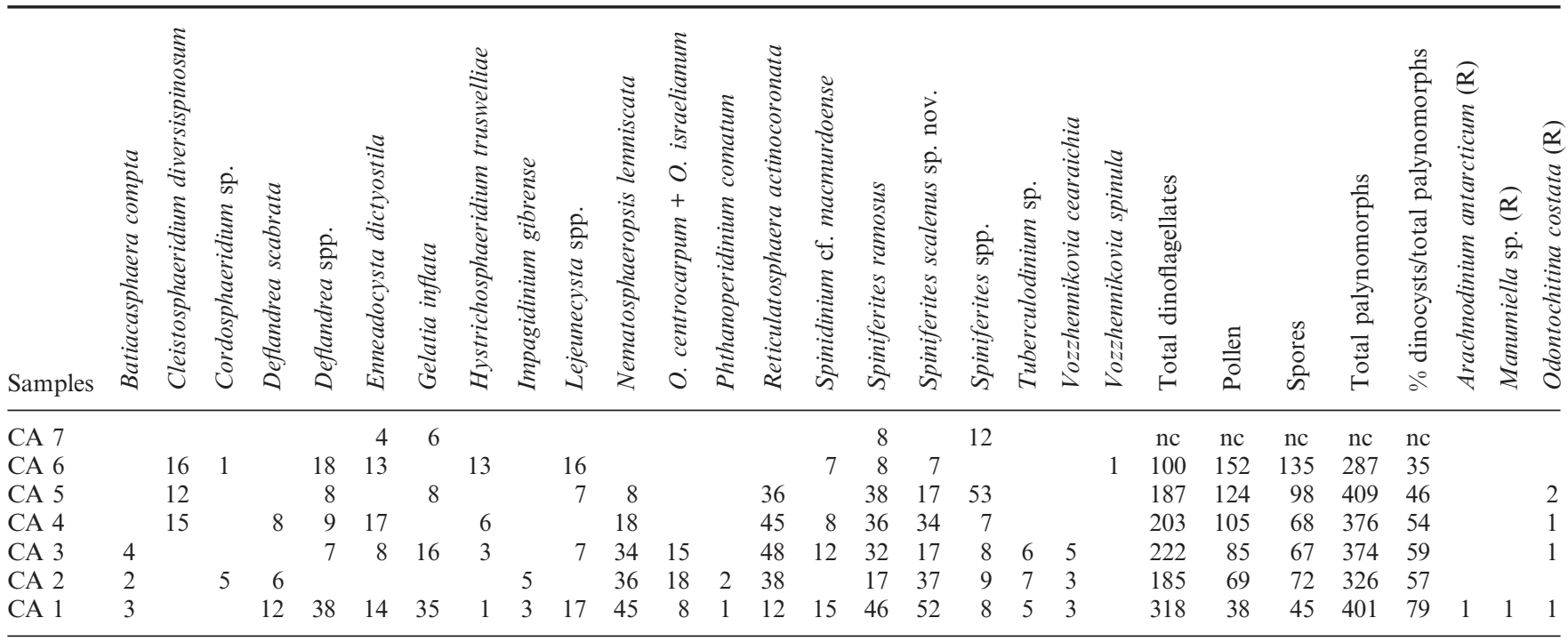

Table 3. Dinocyst distribution within samples from the Cabo Peña Formation at the Cerro Águila section (raw data)

above and warming events during the generally cool late Middle Eocene.

Mohr (1990) interpreted the decrease in dinocyst diversity in ODP Leg 113 samples from the Weddell Sea as reflecting cooling water masses in the Late Eocene. Sluijs et al. (2003) and Stickley et al. (2004) recognized that in the Priabonian, at about 35.5 Ma, the association dominated by the endemic Antarctic flora was replaced by more cosmopolitan and open marine assemblages, with abundant protoperidinioids. This change, which reflects different oceanographical and environmental conditions, was related to the deepening of the Tasmanian Gateway.

The same differences were observed between the La Despedida and Cabo Peña formations in Tierra del Fuego, although there appears to be a stratigraphical gap between the late Middle Eocene and the latest Eocene. It is believed that this 


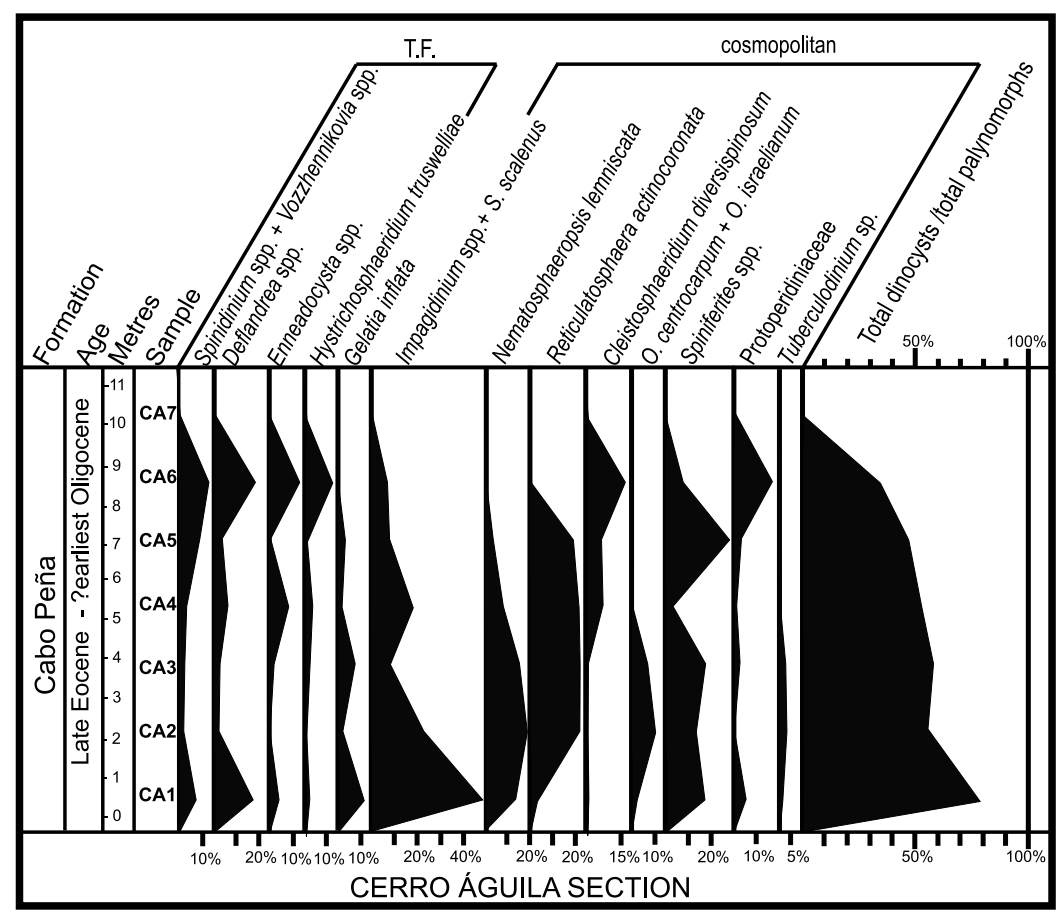

Fig. 9. Quantitative distribution of selected dinocyst groups within samples from the Cabo Peña Formation at the Cerro Águila section. The graph at the right shows ratio of dinocysts to total of palynomorphs. T.F., endemic 'Transantarctic Flora'.

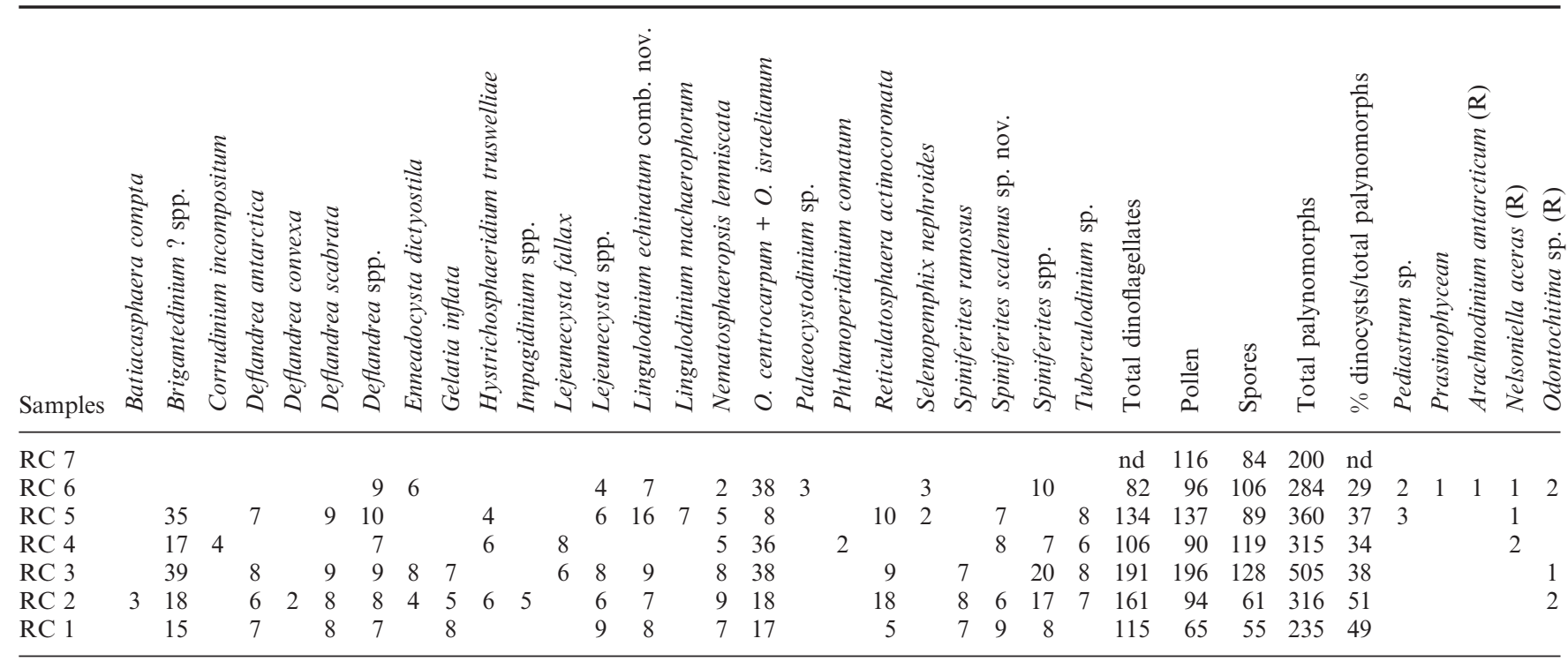

Table 4. Dinocyst distribution within samples from the Cabo Peña Formation at the Río Candelaria section (raw data)

represents two different second-order depositional cycles. The endemic Antarctic flora is well represented in the Middle Eocene lower member of the La Despedida Formation. Also, deepmarine conditions are clearly reflected in the lower part of the Cabo Peña Formation. In the upper part of the three sections of the Cabo Peña Formation, the increasing continental influence and regressive trends might be related to eustatic lowering of sea-level by the growth of Antarctic ice sheets towards the latest
Eocene-earliest Oligocene. In a re-interpretation of geophysical data, related to the rifting history of basins in the Scotia Sea, Livermore et al. (2007) suggested that an ocean gateway may have developed during the Middle Eocene. This new plate tectonic model suggests that even a shallow Drake Passage could have caused the climatic changes in Southern Ocean circulation, which were responsible for Eocene cooling and development of Antarctic ice sheets. 


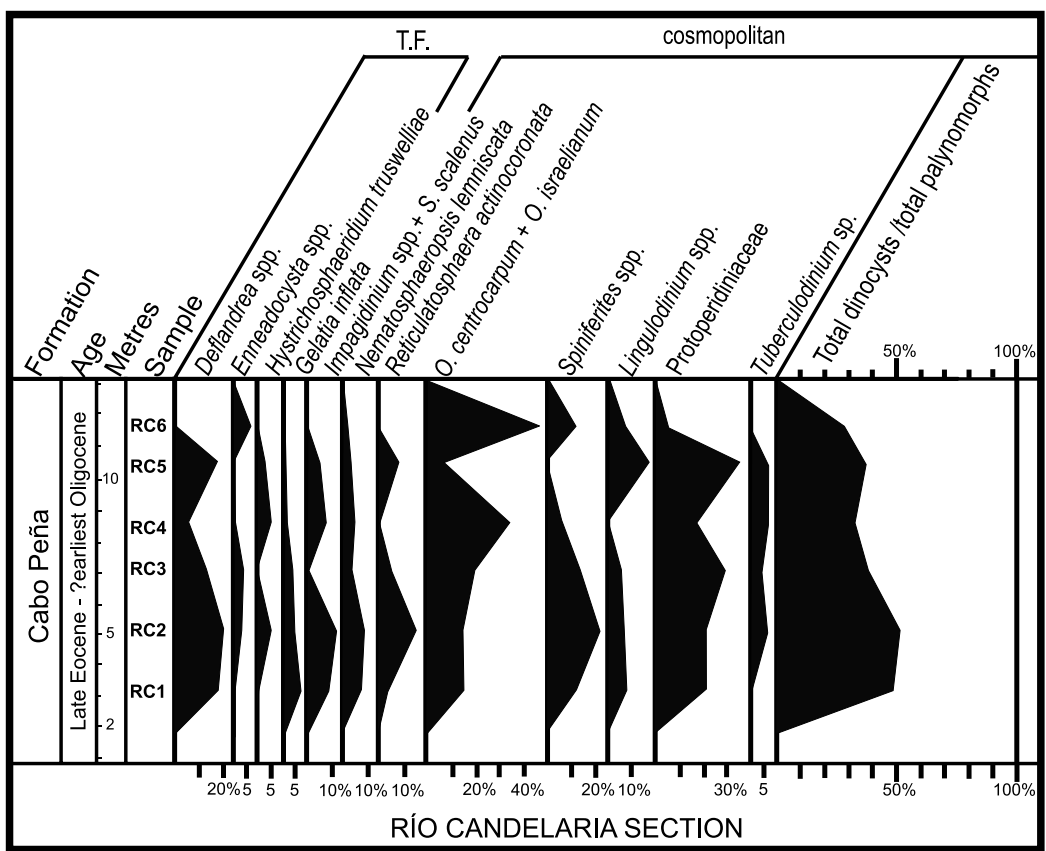

Fig. 10. Quantitative distribution of selected dinocyst groups within samples from the Cabo Peña Formation at the Río Candelaria section. The graph at the right shows ratio of dinocysts to total of palynomorphs. T.F., endemic 'Transantarctic Flora'.

\section{CONCLUSIONS}

Based on dinocyst assemblages, the lower member of the La Despedida Formation is considered to be Middle to Late Eocene in age. This agrees with calcareous microfossil data, mainly benthic and planktonic foraminifera (Codignotto \& Malumián, 1981; Malumián, 1988).

The endemic 'Transantarctic flora' reflects marginal marine conditions, with a restricted connection to the open sea during the Middle Eocene. The Enneadocysta peak may be related to relatively more open conditions and slightly warmer coastal waters.

The Cabo Peña Formation, in its type area, is no older than Late Eocene and the uppermost deposits may extend into the earliest Oligocene.

All three sections of the Cabo Peña Formation contain cool water, heterotrophic dinocysts, plus increasing numbers of cosmopolitan, open-marine species. Regressive trends can be identified in the upper parts of the sections.

Thus, these data are consistent with other palaeoclimatic records from the Southern Hemisphere that suggest a temperature decrease during the earliest Oligocene (Zachos et al., 2001). Furthermore, the presence of cold-water dinocysts reflects the incipient development of the Antarctic Circumpolar Current during the Eocene-Oligocene transition. This oceanographical change is considered a key event in climatic change from a greenhouse to an icehouse Earth.

\section{ACKNOWLEDGEMENTS}

The authors thank O. Cárdenas, B. J. Crilley, and A. Henry for technical assistance; H. Camacho, C. Del Río and M. Quiroga for the help in the field. A. Sweet and F. Thomas helped to considerably improve a previous version of the manuscript with their comments. C. Jaramillo, J. Powell and F. J. Gregory are thanked for interesting suggestions on the manuscript, which led to significant improvements. This study was funded by grants from the Agencia Nacional de Promoción Científica y Tecnológica (PICT 07-26057), from the Consejo Nacional de Investigaciones Científicas y Técnicas (PIP 6416) and Universidad Nacional del Sur. This is Geological Survey of Canada contribution no. 20060138.

List of dinocyst species cited in the text

Full references can be found in Fensome \& Williams (2004). "(R)" denotes those species considered to be reworked.

Alisocysta margarita Harland, 1979 (R)

Arachnodinium antarcticum Wilson \& Clowes, 1982

Areosphaeridium diktyoplokum (Klumpp, 1953), emend. Eaton,

1971. Stover \& Williams, 1995.

Batiacasphaera compta Drugg, 1970

Cleistosphaeridium diversispinosum Davey et al., 1966

Corrudinium incompositum (Drugg, 1970) Stover \& Evitt, 1978

Deflandrea antarctica Wilson, 1967

Deflandrea convexa Wilson, 1988

Deflandrea cygniformis Pöthe de Baldis, 1966

Deflandrea granulata Menéndez, 1965

Deflandrea scabrata Wilson, 1988

Enneadocysta dictyostila (Menéndez) Stover \& Williams, emend.

Fensome et al., 2007

Enneadocysta brevistila Fensome et al., 2007

Enneadocysta partridgei Stover \& Williams, 1995

Gelatia inflata Bujak, 1984

Glaphyrocysta retiintexta (Cookson, 1965) Stover \& Evitt, 1978

(R)

Homotryblium abbreviatum Eaton, 1976

Hystrichosphaeridium? echinatum Menéndez, 1965

Hystrichosphaeridium truswelliae Wrenn \& Hart, 1988 
Hystrichosphaeridium tubiferum (Ehrenberg, 1938) Deflandre, 1937, emend. Davey \& Williams, 1966

Impagidinium gibrense Michoux, 1985

Lejeunecysta fallax (Morgenroth, 1966) Artzner \& Dörhöfer, 1978, emend. Biffi \& Grignani, 1983.

Lingulodinium echinatum Menéndez, 1965 comb. nov.

Lingulodinium machaerophorum (Deflandre \& Cookson, 1955) Wall, 1967

Lingulodinium pycnospinosum (Benedek, 1972) Stover \& Evitt, 1978, emend. Benedek \& Sarjeant, 1981

Nelsoniella aceras Cookson \& Eisenack, 1960 (R)

Nematosphaeropsis lemniscata (Bujak, 1984) Wrenn, 1988

Odontochitina costata (Alberti, 1961, emend) Clarke \& Verdier, 1967 (R)

Oligosphaeridium complex (White, 1842) Davey \& Williams, 1966 (R)

Operculodinium centrocarpum (Deflandre \& Cookson, 1955) Wall, 1967

Operculodinium israelianum (Rossignol, 1962) Wall, 1967

Phthanoperidinium comatum (Morgenroth, 1966) Eisenack \& Kjellström, 1972

Phthanoperidinium echinatum Eaton, 1976

Pyxidinopsis delicata Wilson, 1988

Reticulatosphaera actinocoronata (Benedek, 1972) Bujak \& Matsuoka, 1986

Selenopemphix nephroides Benedek, 1972, emend. Bujak in Bujak et al., 1980

Selenopemphix selenoides Benedek, 1972, emend. Bujak in Bujak et al., 1980

Sepispinula ancorifera (Cookson \& Eisenack, 1960) Islam, 1993, emend. Cookson \& Eisenack, 1968 (R)

Spinidinium sp. cf. S. macmurdoense (Wilson, 1967) Lentin \& Williams, 1976

Spiniferites ramosus (Ehrenberg, 1838) Mantell, 1854

Spiniferites scalenus sp nov.

Thalassiphora pelagica (Eisenack, 1954) Eisenack \& Gocht, 1960, emend. Benedek \& Gocht, 1981

Turbiosphaera filosa (Wilson, 1967) Archangelsky, 1969

Vozzhennikovia apertura (Wilson, 1967) Lentin \& Williams, 1976

Vozzhennikovia cearaichia Stover \& Hardenbol, 1994

Vozzhennikovia spinula Stover \& Hardenbol, 1994

\section{Manuscript received 13 June 2006 \\ Manuscript accepted 18 January 2008}

\section{REFERENCES}

Archangelsky, S. 1969. Estudio del paleomicroplancton de la Formación Río Turbio (Eoceno), Provincia de Santa Cruz. Ameghiniana, 6: 181-218.

Barker, P.F. 2001. Scotia Sea regional tectonic evolution: implications for mantle flow and palaeocirculation. Earth-Science Reviews, 55 (2001): 1-39.

Benedek, P.N. \& Sarjeant, W.A.S. 1981. Dinoflagellate cysts from the middle and Upper Oligocene of Tönisberg (Niederrheingebiet): a morphological and taxonomic restudy. Nova Hedwigia, 35: 313-356.

Biddle, K.T., Uliana, M.A., Mitchum, R.M. Jr, Fitzgerald, M.G. \& Wright, R.C. 1986. The stratigraphy and structural evolution of the central and eastern Magallanes basin, southern South America. International Association of Sedimentologists, Special Publication, 8: $41-61$.
Brinkhuis, H. 1994. Late Eocene to Early Oligocene dinoflagellate cysts from the Priabonian type-area (northeast Italy); biostratigraphy and paleoenvironmental interpretation. Palaeogeography, Palaeoclimatology, Palaeoecology, 107: 121-163.

Brinkhuis, H. \& Biffi, U. 1993. Dinoflagellate cyst stratigraphy of the Eocene/Oligocene transition in central Italy. Marine Micropaleontology, 22 (1): 131-183.

Brinkhuis, H., Sengers, S., Sluijs, A., Warnaar, J. \& Williams, G.L. 2003a. Latest Cretaceous to earliest Oligocene, and Quaternary dinoflagellate cysts from ODP Site 1172, East Tasman Plateau. In: Exon, N.F., Kennett, J.P. \& Malone, M. (Eds), Proceeding of the Ocean Drilling Program. Scientific Results, 189: 1-48. [Available from World Wide Web: http://www. odp.tamu.edu/publications/189_SR/ 106/106.htm.].

Brinkhuis, H., Munsterman, D.M., Sengers, S., Sluijs, A., Warnaar, J. \& Williams, G.L. 2003b. Late Eocene to Quaternary dinoflagellate cysts from ODP Site 1168, off western Tasmania. In: Exon, N.F., Kennett, J.P. \& Malone, M. (Eds), Proceeding of the Ocean Drilling Program. Scientific Results, 189: 1-36. [Available from World Wide Web: http:// www-odp.tamu.edu/publications/189_SR/105/105.htm.].

Bujak, J.P. 1984. Cenozoic dinoflagellate cysts and acritarchs from the Bering Sea and northern North Pacific, D.S.D.P. Leg 19. Micropaleontology, 30 (2): 180-212.

Bujak, J.P. \& Mudge, D. 1994. A high-resolution North Sea Eocene dinocyst zonation. Journal of the Geological Society, London, 151: $449-462$.

Cocozza, C.D. \& Clarke, C.M. 1992. Eocene microplankton from La Meseta Formation, northern Seymour Island. In: Duane, A.M., Pierrie, D. \& Riding, J.B. (Eds). Palynology of the James Ross Island area, Antarctic Peninsula. Antarctic Science, 4 (3): 355-362.

Codignotto, J.O. \& Malumián, N. 1981. Geología de la región al norte del paralelo $54^{\circ} \mathrm{S}$ de la Isla Grande de Tierra del Fuego. Asociación Geológica Argentina, Revista, 36 (1): 44-58.

De Ferrariis, C. 1938. [en Fossa Mancini, E., Feruglio, E. y Yussen de Campana, J.C. 1938]. Una reunión de geólogos de YPF y el problema de la terminología estratigráfica. Boletín de Informaciones Petroleras, 171: 43-44, 94-95.

DeConto, R.M. \& Pollard, D. 2003. Rapid Cenozoic glaciation of Antarctica induced by declining atmospheric $\mathrm{CO}_{2}$. Nature, 421: 245-249.

Dodge, J.D. 1989. Some revisions of the family Gonyaulacaceae (Dinophyceae) based on a scanning electron microscope study. Botanica Marina, 32: 275-298.

Doello-Jurado, M. 1922. Note preliminaire sur les resultats géologiques de L'Expédition de L'Université de Buenos-Ayres a la Terre de Feu (1921). Compte Rend. XIII Sess. Congres Géologique Internacional, Belgique, Liège, 1519-1520.

Edwards, L.E. \& Andrle, V.A.S. 1992. Distribution of selected dinoflagellate cysts in modern marine sediments. In: Head, M.J. \& Wrenn, J.H. (Eds), Neogene and Quaternary Dinoflagellate Cysts and Acritarchs. American Association of Stratigraphic Palynologists Foundation, Dallas, 259-288.

Fensome, R.A. \& Williams, G.L. 2004. The Lentin and Williams Index of Fossil Dinoflagellates 2004 edition. American Association of Stratigraphic Palynologists, Contributions Series, 42: 909pp.

Fensome, R.A., Guerstein, G.R. \& Williams, G.L. 2007. The Paleogene dinoflagellate cyst genera Enneadocysta and Licracysta gen. nov.: new insights based on material from offshore eastern Canada and the Southern Hemisphere. Micropaleontology, 52 (5): 385-410.

Furque, G. \& Camacho, H.H. 1949. El Cretácico Superior de la costa Atlántica de Tierra del Fuego. Revista de la Asociación Geológica Argentina, 21: 263-297.

Gradstein, F., Ogg, J. \& Smith, A. 2004. A geologic time scale. Cambridge University Press, Cambridge, 589pp.

Guerstein, G.R., Chiesa, J.O., Guler, M.V. \& Camacho, H.H. 2002. Bioestratigrafía basada en quistes de dinoflagelados de la Formación Cabo Peña (Eoceno terminal - Oligoceno temprano), Tierra del Fuego, Argentina. Revista Española de Micropaleontología, 34: 105-116.

Guerstein, G.R., Guler, M.V., Daners, G. \& Archangelsky, S. 2003. Quistes de dinoflagelados del Eoceno Medio del Atlántico Sudoccidental y su correlación con otros sitios del Hemisferio Sur. Ameghiniana, suplemento, 40 (4): 87R. 
Guler, M.V. 2003. Quistes de dinoflagelados de la familia Protoperidiniaceae del Neógeno de la cuenca del Colorado, Argentina. Ameghiniana, 40 (3): 457-467.

Haskell, T.R. \& Wilson, G.J. 1975. Palynology of sites 280-284, Deep Sea Drilling Project Leg 29, off southeastern Australia and western New Zealand. In: Kennett, J.P., et al. (Eds), Initial Reports of the Deep Sea Drilling Project, 29: 723-741.

Head, M.J. \& Norris, G. 1989. Palynology and dinocyst stratigraphy of the Eocene and Oligocene in ODP Leg 105, Hole 647a, Labrador Sea. In: Srivastava, S.P., Arthur, M. \& Clement, B. (Eds), Proceedings of the Ocean Drilling Program, Scientific Results, 105: 515-550.

Head, M.J. \& Westphal, H. 1999. Palynology and paleoenvironments of a Pliocene carbonate platform: the Clino Core, Bahamas. Journal of Paleontology, 73 (1): 1-25.

Head, M.J., Norris, G. \& Mudie, P.J. 1989a. Palynology and dinocyst stratigraphy of the Miocene in Ocean Drilling Program Leg 105, Hole 645E, Baffin Bay. In: Srivastava, S.P., Arthur, M. \& Clement, B. (Eds), Proceedings of the Ocean Drilling Program, Scientific Results, 105: 467-514.

Head, M.J., Norris, G. \& Mudie, P.J. 1989b. New species of dinocysts and a new species of acritarch from the upper Miocene and lowermost Pliocene, Ocean Drilling Program Leg 105, Site 646, Labrador Sea. In: Srivastava, S.P., Arthur, M. \& Clement, B. (Eds), Proceedings of the Ocean Drilling Program, Scientific Results, 105: 453-466.

Huber, M., Brinkhuis, H., Stickley, C.E., et al. 2004. Eocene circulation of the Southern Ocean: was Antarctica kept warm by subtropical waters? Paleoceanography, 19: PA4026, doi: 10.1029/2004PA001014.

Kennett, J.P. 1977. Cenozoic evolution of Antarctic glaciation, the circum-Antarctic ocean, and their impact on global paleoceanography. Journal of Geophysical Research, 82: 3843-3859.

Klumpp, B. 1953. Beitrag zur Kenntnis der Mikrofossilen des mittleren und oberen Eozën. Palaeontographica, Abt. A, 103: 377-406.

Lawver, L.A. \& Gahagan, L.M. 2003. Evolution of Cenozoic seaways in the circum-Antarctic region. Palaeogeography, Palaeoclimatology, Palaeoecology, 198: 11-37.

Lentin, J.K. \& Williams, G.L. 1976. A monograph of fossil peridinioid dinoflagellate cysts. Bedford Institute of Oceanography, Report Series, BI-R-75-16: 237pp.

Lentin, J.K. \& Williams, G.L. 1993. Fossil dinoflagellates: index to genera and species. 1993 edition. American Association of Stratigraphic Palynologists, Contribution Series, 28: 856pp.

Livermore, R., Nankivell, A., Eagles, G. \& Morris, P. 2005. Paleogene opening of Drake Passage. Earth Planetary Science Letters, 236: $459-470$

Livermore, R., Hillenbrand, C.D., Meredith, M. \& Eagles, G. 2007. Drake Passage and Cenozoic climate: an open and shut case? Geochemistry Geophysics Geosystems, 8: Q01005, doi:10.1029/ 2005 GC001224.

Malumián, N. 1988. Foraminíferos bentónicos de la localidad tipo de la Formación La Despedida (Eoceno, Isla Grande de Tierra del Fuego). Parte I, Textulariina y Miliolina. Ameghiniana, 25 (4): 341-356.

Malumián, N. 1999. La sedimentación y el volcanismo terciarios en la Patagonia Extraandina. In: Caminos, R. (Ed.), Geología Argentina. Instituto de Geología y Recursos Minerales, Anales, 29 (18): 557-612.

Malumián, N. 2002. El terciario marino, sus relaciones con el eustatismo. In: Haller, M.J. (Ed.), Geología y Recursos Naturales de Santa Cruz. Velatorio del XV Congreso Geológico Argentino. El Calafate, 1-15: 237-244.

Malumián, N. \& Caramés, A.A. 1989. Foraminíferos uniloculares de ornamentación no reticulada (Eoceno-Oligoceno) Tierra del Fuego, Argentina. Ameghiniana, 26: 103-137.

Malumián, N. \& Olivero, E.B. 2006. El Grupo Cabo Domingo, Tierra del Fuego: Bioestratigrafía, Paleoambientes y acontecimienos del Eoceno-Mioceno marino. Revista de la Asociación Geológica Argentina, 61: 139-160.

Mantell, G.A. 1850. A pictorial atlas of fossil remains consisting of coloured illustrations selected from Parkinson's "Organic Remains of a Former World", and Artis's "Antediluvian Phytology". xii+207 pp, 74 plates. Henry G. Bohn, London.

Mao, S. \& Mohr, B.A.R. 1995. Middle Eocene dinoflagellate paleoenvironmental and paleogeographic conclusions. Review of Palaeobotany and Palynology, 86: 235-263.
Menéndez, C.A. 1965. Microplancton fósil de sedimentos terciarios y cretácicos del norte de Tierra del Fuego (Argentina). Ameghiniana, 4: $7-15$.

Mohr, B.A.R. 1990. Eocene and Oligocene sporomorphs and dinoflagellate cysts from Leg 113 drill sites, Weddell Sea, Antarctica. In: Barker, P.F., Kennett, J.P., et al. (Eds), Proceedings of the Ocean Drilling Program, Scientific Results, 113: 595-612.

Olivero, E.B. \& Malumián, N. 1999. Eocene stratigraphy of southern Tierra del Fuego Island, Argentina. American Association of Petroleum Geologists Bulletin, 83 (2): 295-313.

Olivero, E.B. \& Malumián, N. 2008. Mesozoic-Cenozoic stratigraphy of the Fueguian Andes, Argentina. Geologica Acta, 6: 5-18.

Pagani, M., Zachos, J.C., Freeman, K.H., Tipple, B. \& Bohaty, S. 2005. Marked decline in atmospheric carbon dioxide concentrations during the Paleogene. Science, 309: 600-603.

Petersen, C.S. \& Methol, E.J. 1948. Nota preliminar sobre rasgos geológicos generales de la porción septentrional de Tierra del Fuego. Revista de la Asociación Geológica Argentina, 3 (4): 279-291.

Pross, J. \& Brinkhuis, H. 2005. Organic-walled dinoflagellate cysts as paleoenvironmental indicators in the Paleogene; a synopsis of concepts. Paläontologische Zeitschrift, 79: 53-59.

Pöthe de Baldis, E.D. 1966. Microplancton del Terciario de Tierra del Fuego. Ameghiniana, 4 (7): 219-228.

Raymo, M.E. \& Ruddiman, W.F. 1992. Tectonic forcing of late Cenozoic climate. Nature, 359: 117-122.

Reid, P.C. 1977. Peridiniacean and glenodiniacean dinoflagellate cysts from the British Isles. Nova Hedwigia, 29: 429-463.

Röhl, U., Brinkhuis, H., Stickley, C.E., Fuller, M., Schellenberg, S.A., Wefer, G. \& Williams, G.L. 2004. Sea level and astronomically induced environmental changes in Middle and Late Eocene sediments from the East Tasman Plateau. In: Exon, N.F., Malone, M. \& Kennett, J.P. (Eds), Climate evolution of the Southern Ocean and Australia's northward flight from Antarctica. American Geophysical Union, Geophysical Monograph Series, 151: 127-151.

Sarjeant, W.A.S. 1970. The genus Spiniferites Mantell, 1850 (Dinophyceae). Grana, 10: 74-78.

Sluijs, A., Brinkhuis, H., Stickley, C.E., Warnaar, J., Williams, G.L. \& Fuller, M. 2003. Dinoflagellate cysts from the Eocene / Oligocene transition in the Southern Ocean; results from ODP Leg 189. In: Exon, N.F., Kennett, J.P. \& Malone, M.J. (Eds), Proceedings of the Ocean Drilling Program, Scientific Results, 189: 1-42. [Available from World Wide Web: http://www-odp.tamu.edu/publications/189_SR/104/104.htm.].

Sluijs, A., Pross, J. \& Brinkhuis, H. 2005. From greenhouse to icehouse; organic-walled dinoflagellate cysts as paleoenvironmental indicators in the Paleogene. Earth-Science Reviews, 68: 281-315.

Stickley, C.E., Brinkhuis, H., Schellenberg, S.A., et al. 2004. Timing and nature of the deepening of the Tasmanian Gateway. Paleoceanography, 19: PA4027, doi: 10.1029/2004 PA001022.

Stover, L.E. \& Williams, G.L. 1995. A revision of the Paleogene dinoflagellate genera Areosphaeridium Eaton 1971 and Eatonicysta Stover and Evitt 1978. Micropaleontology, 41 (2): 97-141.

Truswell, E.M. 1997. Palynomorph assemblages from marine Eocene sediments on the West Tasmanian continental margin and the South Tasman Rise. Australian Journal of Earth Sciences, 4: 633-654.

Wall, D. 1967. Fossil microplankton in deep sea cores from the Caribbean Sea. Palaeontology, 10: 95-123.

Williams, G.L., Brinkhuis, H., Bujak, J.P., Damassa, S.P., Hochuli, P.A., de Verteuil, L. \& Zevenboom, D. 1998. Dinoflagellates. Appendix to Mesozoic and Cenozoic sequence chronostratigraphic framework of European Basins. In: Hardenbol, J., Thierry, J., Farley, M.B., Jacquin, T., de Graciansky, P.-C. \& Vail, P.R. (Eds), Mesozoic and Cenozoic Sequence Stratigraphy of European Basins. Society for Sedimentary Geology, Special Publication, 60: 9pp. and chart 3.

Williams, G.L., Brinkhuis, H., Pearce, M.A., Fensome, R.A. \& Weegink, J.W. 2004. Southern Ocean and global dinoflagellate cyst events compared; index events for the late Cretaceous-Neogene. In: Exon, N.F., Kennet, J.P. \& Malone, M.J. (Eds), Proceeding of the Ocean Drilling Program. Scientific Results, 189: 1-98. [Available from World Wide Web http://www-odp.tamu.edu/publications/189_SR/107/107.htm.].

Wilson, G.J. 1988. Palaeocene and Eocene dinoflagellate cysts from Waipawa, Hawkes Bay, New Zealand. New Zealand Geological Survey, Paleontological Bulletin, 57: 1-96. 
Wrenn, J.H. \& Beckman, S.W. 1982. Maceral, total organic carbon, and palynological analyses of Ross Ice Shelf Project site J9 cores. Science, 216: $187-189$.
Zachos, J.C., Pagani, M., Sloan, L.C., Thomas, E. \& Billups, K. 2001. Trends, rhythms, and aberrations in global climate 65 Ma to present. Science, 292: 686-693. 